\title{
A IDÉIA DE CUITURA TEUTO-BRASILEIRA: LITERATURA, IDENTIDADE E OS SIGNIFICADOS DA ETNICIDADE
}

\section{Giralda Seyferth \\ Museu Nacional/Universidade Federal do Rio de Janeiro - Brasil}

Resumo: No contexto da imigração alemã, ainda no século XIX, surgiu uma literatura produzida por indivíduos atentos à realidade cultural teuto-brasileira, e que prosperou até 1939, quando o Estado Novo proibiu as publicações em idioma estrangeiro durante a "campanha de nacionalização". Neste artigo procuro analisar o papel exercido por essa literatura escrita em língua alemã especialmente a poesia - na construção de uma identidade cultural que combina os princípios da germanidade com a realidade da colonização em território brasileiro. O universo focalizado é o da "colônia" Blumenau (Vale do Itajaí, SC), lugar onde uma elite emergente, com algum capital cultural e, principalmente econômico, patrocinou atividades associativas, manteve um teatro e estimulou a produção literária divulgada, principalmente, através de jornais e almanaques, numa apropriação bastante peculiar da noção de Kultur.

Palavras-chave: colonização alemã, germanidade, identidade cultural, literatura teuto-brasileira.

Abstract: Within the context of German immigration to Brazil, texts produced by individuals alert to the cultural realities of Teuto-Brazilian life began to be produced in the 19th century. This literature thrived until 1939 when the Nationalization Campaign of Getulio Vargas' Estado Novo prohibited the publication of texts written in foreign languages. In this article, I seek to analyze the role played by German language literature produced in Brazil - especially poetry - in the construction of a cultural identity which combined the principles of "Germanhood" with the realities of colonial life in Brazilian territory. The social universe I focus upon is "colony" of Blumenau in the Itajaí Valley in the state of Santa Catarina. There, an emerging elite, which possessed cultural and economic capital, supported a variety of associative activities, maintained a theater and stimulated literary production and distribution, principally through 
newspapers and almanacs, in a very peculiar appropriation of the notion of Kultur.

Keywords: cultural identity, german-brazilian literature, german colonization, germanness.

Na conclusão do livro sobre a colonização alemã no Brasil, publicado em 1946, Emílio Willems recorreu à noção de “cultura híbrida” para afirmar a especificidade cultural teuto-brasileira, numa tentativa de superar certos limites dos conceitos de assimilação e aculturação então vigentes nas análises de processos migratórios. O hibridismo cultural contém o pressuposto da duplicidade resultante do contato dos imigrantes e seus descendentes com o meio ambiente, a sociedade e a cultura brasileiras, expressado pelo uso analítico da categoria teuto-brasileiro (Deutschbrasilianer ou Deutschbrasilianisch). Nos termos de Willems esse hibridismo resulta da marginalidade de uma população ambivalente entre duas culturas (alemã e brasileira), que produziu uma terceira, quase que essencialmente rural (apesar das inserções urbanas), em conflito de lealdades dentro do Estado brasileiro. O reconhecimento dessa singularidade construída pelo conflito, porém, é observado pela concepção teórica de "homem marginal” vinculada, desde seu enunciado por Robert E. Park (1928), à figura do imigrante. Esse conceito supõe a coexistência de atitudes e valores provenientes de duas culturas distintas, com a conseqüente possibilidade de conflitos e desajustamentos comportamentais de natureza psicológica, daí o uso da expressão "marginalidade cultural”. ${ }^{1}$ A dualidade cultural seria a principal característica da marginalidade em contextos migratórios, onde "padrões de comportamento, oriundos de culturas diversas, chocam-se através de dois ou mais grupos em contato” (Willems, 1980, p. 120). Essa contextualização marginal da cultura teuto-brasileira atravessa a análise de Willems, voltada para o processo de aculturação desde o trabalho

${ }^{1}$ O conceito, inicialmente formulado por Park (1928) foi posteriormente reelaborado, em 1937, por E. V. Stonequist (1948), em grande parte referido à situação subordinada de grupos migrantes e minorias raciais. 
anterior (Willems, 1940), significativamente intitulado Assimilação e Populações Marginais no Brasil: em ambos os textos é notória a influência de Stonequist (1948) e, particularmente, do estudo de Thomas e Znaniecki sobre os poloneses emigrados para a cidade de Chicago, publicado em 1918, também voltado para questões de marginalidade cultural e desajustamento que seriam características da segunda geração de imigrantes (Thomas; Znaniecki, 1974).

À parte as limitações do conceito de "homem marginal”, pode-se dizer que Willems, embora relutante, usou “cultura híbrida” para explicitar uma integração cultural especificamente teuto-brasileira, diferenciada das suas origens germânicas, em processo de aculturação que incorporou “considerável número de elementos da cultura brasileira” (Willems, 1980, p. 415). Não há uma aceitação tácita da peculiaridade teuto-brasileira apregoada em grande parte da bibliografia e nas fontes jornalísticas, literárias e documentais produzidas nas regiões de colonização alemã utilizadas por Willems, e que apontam para uma concepção de identidade cultural que expressa etnicidade, coexistindo com a assimilação. Assim, a formulação da cultura híbrida atendeu aos imperativos do conceito de aculturação, referido aos fenômenos que ocorrem quando grupos de indivíduos portadores de diferentes culturas entram em contato, com as subseqüentes mudanças nos padrões culturais originais dos grupos envolvidos. ${ }^{2} \mathrm{O}$ uso concomitante da concepção de marginalidade atendeu ao princípio da transitoriedade das situações de conflito interétnico, e as diferenças culturais acionadas como elementos de distinção grupal são percebidas como forma de evitar desajustamentos sociais próprios dos processos de assimilação. Cultura híbrida, portanto, tem significado bem preciso em meados da década de 1940: é um indicador da "cultura marginal” de descendentes de imigrantes, e suas muitas variações regionais urbanas e rurais são materializadas por padrões de integração grupal que distanciam a maior parte da população teuto-brasileira da sociedade nacional e até mesmo dos imigrantes recém-chegados, identificados pela categoria alemão-novo (Neudeutscher). Observando as dificuldades da demonstração empírica empreendida por Willems na análise da aculturação, é possível perceber

\footnotetext{
2 Willems utilizou conceitos produzidos pela antropologia cultural norte-americana para análise da situação de contato interétnico, em particular os textos de Redfield, Linton e Herskovits (1935) e Linton (1940).
} 
como esse recurso teórico o levou a pormenorizar muito mais os elementos diferenciadores de uma formação cultural específica, presentes nas chamadas "colônias alemãs". Faz isso de forma mais sistemática nos oito capítulos da segunda parte do livro de 1946, um dos mais dedicado à literatura e imprensa (Willems, 1980, p. 392-402). Não deu muita importância à produção literária, chamada "literatura de almanaque e jornal”, numa reprovação estética reforçada pela referência aos veículos mais comuns da divulgação, mas aponta para algumas temáticas indicadoras de conflito interétnico e para uma linguagem escrita peculiar e quase ininteligível aos “alemães natos".

Expressão educada da cultura híbrida, essa literatura tem sido considerada de baixa qualidade formal e destinada a um público apenas alfabetizado, não erudito, e demonstrativa da "ambivalência”, "dualidade” e particularismo dos descendentes de imigrantes, conforme os poucos trabalhos acadêmicos, além dos textos de Willems, a ela dedicados (Kuder, 1936/37; Huber, 1979, 1993, 2002, 2003). Tendo em vista a noção de cultura teuto-brasileira evidenciada por Willems, e o papel exercido pela literatura em língua alemã produzida no Brasil até 1939, pretendo abordar as formas arbitrárias e contingentes de construção de uma identidade coletiva, fundamentada na idéia de Kultur, contidas nos escritos de indivíduos pertencentes às elites locais, sobretudo na poesia destacada nas publicações comemorativas da imigração e colonização. A produção literária teutobrasileira foi bastante significativa até 1939, ano da proibição de publicações em idioma estrangeiro no contexto da intensificação da "campanha de nacionalização” do Estado Novo. ${ }^{3}$ Explica-se a preocupação nacionalista, pois, além do uso de um idioma estrangeiro - fato considerado problemático para a formação nacional dada a relevância da língua vernácula na definição do Estado-Nação - o conteúdo dos romances, contos e, sobretudo, da poesia teuto-brasileira remete a uma concepção de identidade fundada na diferença cultural característica de sistemas interétnicos, traduzida numa forma literária acessível aos colonos através da imprensa e publicações periódicas

\footnotetext{
3 Tratei da campanha de nacionalização em outro texto (Seyferth, 1999a). Aqui deve ser mencionado que esse projeto nacionalista instituiu a assimilação forçada de imigrantes e descendentes com o objetivo de chegar à unidade da nação numa configuração luso-brasileira. Nessa perspectiva, a imposição da língua vernácula tornou-se imprescindível inclusive para autores que não concordavam com os princípios mais repressivos e ostensivamente violentos da campanha - ver, por exemplo, o opúsculo de Gilberto Freyre (1940).
}

Horizontes Antropológicos, Porto Alegre, ano 10, n. 22, p. 149-197, jul./dez. 2004 
igualmente condenadas pelo nacionalismo. A produção literária objeto deste artigo foi divulgada em Santa Catarina, principalmente em Blumenau, a mais notória das "colônias alemãs" daquele estado, cuja relevância política (especialmente na Primeira República) pôs em evidência uma elite local empenhada na preservação dos valores culturais germânicos sem perder de vista a inserção na sociedade nacional, valorizando a cidadania brasileira e o território. Na região mais densamente povoada por imigrantes alemães havia espaço para divulgação dos escritos de autores teuto-brasileiros em geral, com destaque para aqueles que nasceram e/ou viveram em Blumenau (e Joinville, o outro pólo da colonização alemã em Santa Catarina). A análise contempla o universo paradigmal desses escritos, especialmente o conteúdo literário da publicação comemorativa do centenário da imigração alemã em Santa Catarina (Entres, 1929), com eventuais referências às publicações de maior alcance editadas em outros lugares e que circularam no Vale do Itajaí. Não se trata de examinar apenas o conteúdo de textos literários, que em grande parte reproduzem certas versões de senso comum sobre a identidade étnica, mas também observar o empenho da parcela mais abonada da sociedade colonial para criar uma tradição singular, evidenciada em textos escritos e publicados em veículos de circulação regional, num momento histórico de exacerbação do nacionalismo brasileiro.

II

Nas primeiras quatro décadas do século XX, particularmente em Blumenau e após a Primeira Guerra Mundial, houve certa efervescência literária, articulada à temática da colonização, nas regiões do Estado de Santa Catarina ocupadas por imigrantes alemães. A data da fundação de Blumenau - 2 de setembro de 1850 - é emblemática da ocupação, signo civilizatório representado pelos 17 imigrantes pioneiros (entre eles quatro crianças) que chegaram de barco para estabelecer as bases da colônia, um empreendimento particular, projeto de Hermann Blumenau devidamente autorizado pelo governo imperial brasileiro. O marco temporal representativo da transcendência da floresta para a civilização, no entanto, deixa em plano secundário um incipiente processo de ocupação ocorrido no baixo Vale do Itajaí em 1835, numa área de terras públicas concedidas a famílias alemãs, egressas da colônia de São Pedro de Alcântara, e a brasileiros ali 
estabelecidos como posseiros. É um fato marginal nas histórias laudatórias da colonização, lembrado nas publicações comemorativas porque entre os assentados estava uma das figuras mais representativas da ascensão social a partir da condição de colono, retratada como exemplo acabado e ideal do pioneiro bem sucedido. ${ }^{4}$

Após a fundação de Blumenau surgiu, em 1851, uma outra colônia D. Francisca (Joinville) - localizada no Norte do estado em território outorgado como dote à irmã do imperador Pedro II; tornou-se o empreendimento de colonização particular mais bem sucedido, com ramificações até o planalto e o alto Vale do Itajaí. Em 1860 o governo imperial estabeleceu um núcleo colonial no rio Itajaí-Mirim, que deu origem à cidade de Brusque. No mesmo ano Blumenau deixou de ser colônia particular: diante das dificuldades financeiras e de aliciamento (sem subsídios) de imigrantes nos estados alemães, o governo imperial assumiu o empreendimento, mantendo o fundador Hermann Blumenau na direção, na condição de funcionário público. As dificuldades de expansão da colônia não eram apenas financeiras: havia, por exemplo, o incômodo causado por um projeto de ocupação territorial envolvendo imigrantes evangélicos-luteranos, condenado pelos nacionalistas da época, que afirmavam o caráter latino e católico da nacionalidade brasileira. Enfim, o ato do governo brasileiro sinalizou para a importância geopolítica atribuída à colonização estrangeira no Sul do país e, provavelmente, salvou o empreendimento do dr. Blumenau, assumindo as despesas com o assentamento dos colonos num contexto legislativo de retorno à imigração subsidiada. ${ }^{5}$ Esse detalhe da história da colonização, porém, não teve nenhum efeito sobre as representações acerca do "pioneirismo" dos heróis que dominaram a natureza brasileira, nem tampouco causou danos à imagem do fundador da colônia, associada a uma utopia bem sucedida.

A localização dos três principais núcleos de povoamento mostra que a

${ }^{4}$ O colono em questão, Pedro Wagner, integrou a primeira leva de imigrantes alemães localizados em 1829 na colônia de São Pedro de Alcântara. Dada essa primazia, e por tratarse de um colono remediado, portanto, bem sucedido como agricultor, tem o perfil imaginado para o "pioneiro".

${ }^{5}$ Apesar da abertura para a iniciativa particular em matéria de imigração e colonização ocorrida após a promulgação da lei de imigração em 1850, e da condenação à prática de subsídios, as dificuldades de atrair fluxos imigratórios espontâneos da Europa fez com que o governo imperial voltasse a contratar os serviços de agenciadores, oferecendo subsídios àqueles que viessem com a família para localização em colônias, cf. Seyferth, 2002a.

Horizontes Antropológicos, Porto Alegre, ano 10, n. 22, p. 149-197, jul./dez. 2004 
colonização alemã concentrou-se na parte mais ao norte da província de Santa Catarina. A continuidade espacial dessa ocupação, em parte realizada por empresas particulares formadas na Europa, deixou em evidência as muitas diferenças socioculturais derivadas da imigração. De fato, o Vale do Itajaí, povoado a partir dos núcleos coloniais de Blumenau e Brusque, o território da colônia D. Francisca (Joinville), na região dos rios São Francisco e Itapocú, e as áreas de expansão da sua empresa fundadora, a Sociedade Colonizadora de 1849 em Hamburgo (que administrou também os núcleos de São Bento do Sul e Jaraguá do Sul), formavam, no início do século XX, uma totalidade geográfica com predominância de população de origem germânica - lugares distintos da sociedade brasileira, onde a língua alemã era o idioma do cotidiano, independentemente das modificações estruturais da linguagem percebidas, inclusive, na escrita literária em prosa, e assinaladas, por exemplo, nos textos de Willems (1940, 1980). Blumenau tornou-se o principal núcleo urbano dessa extensa região, e centro irradiador do ideário de uma germanidade (Deutschtum) "brasileira”, embora sua notoriedade não estivesse restrita ao crescimento industrial, igualmente relevante nas cidades de Joinville e Brusque, e sim à proeminência política do município criado em 1881 que, na década de 1920 (antes do seu desmembramento), era o maior colégio eleitoral do estado.

Em cada uma dessas pequenas cidades, e mais intensivamente em Blumenau, as elites e classes médias locais, formadas por comerciantes, industriais, políticos e funcionários públicos, educadores, pastores, jornalistas, profissionais liberais, etc., criaram condições para o surgimento de associações que pudessem valorizar a cultura dos imigrantes, inclusive no seu aspecto mais erudito ou sofisticado, vinculado a uma idéia de cultura derivada do Romantismo alemão. Por isso mesmo, as palavras Deutschtum, Volkstum e Kultur são usadas como marcadores da diferença cultural mais intensivamente do que as traduções dicionarizadas, que apontam, respectivamente, para germanismo, nacionalidade (alemã) e cultura/ civilização, sugerem. Termos conceituais como Volkstum ou Deutschtum remetem à idéia de uma cultura popular apropriadamente germânica, construída na longa duração, mas o significante nacional inclui também uma noção de pertencimento comunitário que, no discurso teuto-brasileiro, está mais próximo de uma representação "nativa” de etnicidade primordial. Há uma reinvenção da "civilização" germânica no território colonizado, que 
incorpora a mudança social e cultural ocasionada pela conversão do emigrante em imigrante, tendo em vista a opção por uma nova Heimat (pátria). Tal conversão, porém, não abre mão dos ideais de Volkstum e Kultur: para a gente educada, vivendo nas cidades emergentes de antigos núcleos coloniais como Blumenau, era possível ter uma alta cultura associada à atividade criadora do "espírito germânico" - música, poesia, romance, teatro, conhecimento da tradição literária em língua alemã, e toda uma sociabilidade marcada pela convivência nos espaços chamados Verein (associação).

Observando o caso de Blumenau é possível perceber o ânimo das camadas mais altas do mundo colonial para conformar uma comunidade étnica imaginada a partir de certos valores do nacionalismo romântico alemão reconfigurados no local. As primeiras associações, destinadas a práticas esportivas, reuniões sociais e atividades culturais, surgiram logo no início da colonização. Significativamente, eram Schützenvereine (portanto, destinadas à prática de tiro) - um tipo de agremiação considerada utilitária (no início) e com raízes nacionalistas. Utilitária porque seus associados eram atiradores, formando uma espécie de linha de defesa colonial, conforme assinalado em textos comemorativos; expressão da "cultura germânica" porque seus salões serviam também para apresentações musicais e teatrais, portanto algo mais do que festas e bailes igualmente vinculados ao "caráter alemão" nos discursos que enfatizam os quatro ff (mais presentes no contexto de outra associação similar, a Turnverein, sociedade de ginástica) - Frisch (lépido), Fromm (devotado), Froelich (alegre) e Frei (livre). Tais rótulos, junto com outro bastante comum nos discursos sobre a colonização - Tüchtigkeit (capacidade, valor) - supõem um princípio moral disciplinador e uma vinculação histórica com a guerra contra a dominação napoleônica, contexto de surgimento do nacionalismo alemão moderno, cujas principais figuras eram os filósofos Fichte e Herder, e o poeta Ernst Moritz Arndt. ${ }^{6}$ Trata-se da formulação inicial do que Hobsbawm (1990, p. 126-127) chamou de “critério etnolingüístico" de definição da nação, que incluiu também a redescoberta folclórica do povo. Resumindo, para além da sociabilidade, as

\footnotetext{
${ }^{6}$ Essa vinculação histórica aparece num texto anônimo que ressalta a Sociedade de Atiradores como "instituição alemã" que os imigrantes trouxeram da "velha pátria”, publicado no folheto comemorativo dos 75 anos de fundação da Schützenverein Brusque (Festschrift zum 75-jährigen Stiftungsfest des Schützenvereins Brusque 14.7.1941).
} 
associações representavam Volkstum: dela participavam "colonos alemães”, que falavam o idioma da "velha pátria".

Não é pouca a relevância dessas associações, assinalada por vários autores que escreveram sobre a imigração alemã no Brasil; sua vinculação com a germanidade levou à intervenção, às vezes violenta, ou simultaneamente ao fechamento, durante a campanha de nacionalização do Estado Novo, período em que as sedes sociais de algumas sociedades de tiro e ginástica do Vale do Itajaí foram transformadas em espaços de acantonamento de tropas do exército (Seyferth, 1999b). As mais importantes estavam situadas no meio urbano, mas, em Blumenau, até as principais linhas coloniais ostentavam suas associações, às vezes funcionando de modo precário em propriedades particulares - caso de grupos dedicados ao canto que se reuniam na casa de um dos participantes - origem de muitas Gesangvereine (sociedades de canto). Foi dessa forma que surgiu, por exemplo, a Gesangverein Sängerbund, em 1865, dedicada ao canto (Lied), música instrumental e, eventualmente, apresentações teatrais. Na mesma época surgiu outro grupo de cantores, a Freundschaftsverein (Sociedade Amizade), cuja fundação foi noticiada no Kolonie Zeitung de Joinville, em 2 de abril de 1864, como uma iniciativa de B. Scheidemantel, desenhista, litógrafo e proprietário de um ateliê fotográfico, com trânsito entre os notáveis da colônia. A primeira Schützenverein é ainda mais antiga, pois foi formalizada, em 1859, pelas lideranças locais (entre as quais figurava com destaque o pastor evangélico-luterano), quando a colônia tinha apenas 749 habitantes. Nos termos da historiadora blumenauense Edith Kormann (1994, p. 31), e dos álbuns comemorativos, a vida social e artística da colônia começou ali, nove anos após a chegada dos pioneiros, e seria consolidada com a criação da sociedade teatral Frohsinn, em 1860. A partir daí, proliferaram as Vereine: na década de 1930 estavam em toda parte, na cidade, nos povoados menores, no interior do município, nas linhas coloniais. Elas possuíam bandeiras, estatutos que em geral também consignavam o uso da língua alemã, e congregavam pessoas de diferentes classes sociais.

O surgimento de associações culturais, recreativas e beneficentes é fato comum em contextos imigratórios. No entanto, olhando para as publicações comemorativas, especialmente para aquelas que celebram cinqüentenários e centenários de associações e fundações de colônias, e para o volume comemorativo da chegada dos primeiros alemães imigrantes 
em Santa Catarina (Entres, 1929), percebe-se que não é só a quantidade que chama a atenção, ${ }^{7}$ mas, principalmente, sua vinculação com o "caráter nacional” germânico traduzido na noção de Deutschtum (germanidade). Lugares de cultivação da vida social, incentivados, no início, pelo próprio fundador da colônia imbuído de ideal comunitário diante da precária situação dos "colonos na selva”, conforme assinala a historiografia sobre Blumenau (Kormann, 1994; Silva, [s.d.]), também funcionavam como espaços de atualização de uma identidade culturalmente marcada pela germanidade e sua reconfiguração na nova pátria (neue Heimat). Essa reconfiguração aparece explicitamente nos escritos literários, em prosa e verso, de autores teuto-brasileiros que, pertencendo ou não às elites locais, freqüentavam tais associações, convivendo com parte do público-alvo das suas publicações os colonos, categoria social que recobre os pequenos proprietários rurais mas, igualmente, qualquer pessoa pertencente à colônia como um todo, que inclui a Stadtplatz (cidade).

De fato, em Blumenau, como em outras áreas de colonização alemã, havia um ambiente favorável à produção literária que fala da imigração, da colonização e, principalmente, da paisagem, do cotidiano, dos costumes (locais e brasileiros) e da língua alemã. Além das associações, havia a imprensa - o veículo mais comum de divulgação -, tipografias e livrarias. No Vale do Itajaí e em áreas próximas, como Joinville, havia vários jornais locais em circulação até 1939, destacando-se Blumenauer Zeitung, Der Urwaldsbote, Rundschau, Kolonie Zeitung. Jornais teuto-brasileiros de outros estados tinham uma circulação mais restrita e urbana - caso do Der Kompass (editado em Curitiba), do Deutsche Zeitung (editado em São Paulo) e do Kozeritz Deutsche Zeitung (editado em Porto Alegre). Havia também os almanaques (Kalender) editados nas regiões de colonização alemã em Santa Catarina, mas o mais popular deles vinha de São Leopoldo (RS) - O Kalender für die Deutschen in Brasilien, conhecido popularmente como o Rotermund Kalender, ${ }^{8}$ mencionado com certa

\footnotetext{
Conforme assinalei em outro trabalho (Seyferth, 1999b, p. 26), não é fácil dimensionar numericamente essas associações que, inclusive, podiam estar reunidas em federações, o que aponta para interesses comuns além das fronteiras estaduais. Roche (1969, p. 646) foi mais preciso na generalização: "pululam as sociedades nas colônias".

8 Trata-se do mais importante Kalender, publicado entre 1881 e 1939 pela Editora Rotermund, de São Leopoldo (RS), fundada pelo pastor Wilhelm Rotermund, figura respeitada nos meios teuto-brasileiros. Parte substantiva desse almanaque era ocupada por textos literários em língua alemã produzidos no Brasil.
}

Horizontes Antropológicos, Porto Alegre, ano 10, n. 22, p. 149-197, jul./dez. 2004 
nostalgia por muitos colonos por mim entrevistados em pesquisa realizada no Vale do Itajaí no início da década de 1980. Em todas essas publicações havia espaço para obras de ficção e, principalmente, poesia, produzidas por autores teuto-brasileiros e, muito eventualmente, para traduções de obras poéticas de autores brasileiros. Poucos autores publicaram seus textos ficcionais na Alemanha, e aqueles que tiveram essa abertura editorial eram mais conhecidos por seus relatos de viagem ou por trabalhos dedicados à história da colonização. ${ }^{9}$

III

Numa observação bastante pertinente, Kuder (1936/37, p. 423) afirmou que a literatura produzida por teuto-brasileiros (nascidos ou não no Brasil) refere-se ao novo ambiente, ao cotidiano difícil nas colônias, aos percalços do percurso migratório, mas, estranhamente, nunca se fala de uma aldeia, mas quase sempre de cidades e centros de civilização. Tal estranhamento tem a ver com a constatação pura e simples de que, principalmente antes da Primeira Guerra Mundial, eram poucos os centros considerados "urbanos" nas áreas coloniais que pudessem ser apropriadamente chamados de cidades. Assim, Blumenau recebeu a designação de Stadtplatz ${ }^{10}$ desde os primórdios, quando as proporções do núcleo colonial mal configuravam uma aldeia: mas tratava-se de um lugar com atribuições urbanas a partir do qual formou-se a cidade, cujo crescimento ocorreu concomitante com o desenvolvimento industrial desde o início do século XX. A temática da cidade (ou urbana), ainda que com proporções aldeãs, tem relação com o sentido civilizatório atribuído à colonização alemã no Brasil, algo presente na literatura, nos textos comemorativos e nos relatos históricos. Mas sendo uma literatura produzida e consumida no lugar - a "colônia alemã" em sentido amplo - aglutina elementos que compõem uma representação sobre a identidade teuto-brasileira, cujo elemento primordial é a gênese histórica da

9 José Deeke e Gustav Stutzer são dois exemplos de autores mais conhecidos por seus trabalhos sobre a história da colonização do que por suas obras de ficção.

${ }^{10}$ A composição da palavra - Stadt $=$ cidade; Platz = lugar - põe em dúvida a pertinência dessa atribuição aos núcleos coloniais: para os colonos são lugares com funções urbanas, onde podiam ter atendimento médico, resolver problemas fundiários, comerciar, encontrar conhecidos e parentes localizados em outras linhas, freqüentar as associações, etc. (cf. Seyferth, 1990, p. 44-45).

Horizontes Antropológicos, Porto Alegre, ano 10, n. 22, p. 149-197, jul./dez. 2004 
criação de uma neue Heimat (nova pátria) situada no Brasil. Os autores, imigrantes da primeira e segunda geração, através de versos, romances, contos e textos de opinião dirigidos aos leitores de jornais e almanaques, instituíram uma nova germanidade em terras brasileiras através do atributo categórico Deutschbrasilianer (ou, com muito menos freqüência, Brasildeutsche). Nessas manifestações escritas que narram uma versão sobre o complexo colonial, de fato, não existe, propriamente, um universo aldeão; há cidades e civilização mas, igualmente, a dor, o sacrifício e os custos humanos das trajetórias imigratórias.

O perfil de alguns autores que nasceram ou viveram nas regiões coloniais de Santa Catarina permitirá melhor entendimento do conteúdo ideológico e do princípio de etnicidade presentes nos seus escritos, e que fazem parte da visão de mundo das elites coloniais. Entre eles, destaca-se Johann Friedrich Georg Ernest Niemeyer, o primeiro da lista de Kuder (1936/37, p. 457) - autor prolixo e contribuinte obstinado dos Kalender. Significativamente, assinava seus escritos como Ernesto Niemeyer (adotando, portanto, um prenome luso). Nasceu em Joinville em 1863, filho mais velho do diretor daquela colônia, o engenheiro Louis Niemeyer. Mais tarde mudou-se para Curitiba, cidade para onde se dirigiram muitos imigrantes inicialmente localizados em Joinville. Tornou-se funcionário público federal, tendo ocupado o cargo de chefe do serviço telegráfico. ${ }^{11}$ Sua obra é bastante variada: publicou romances e novelas, escreveu inúmeras crônicas para jornais e almanaques e destacou-se como poeta. Suas poesias foram publicadas, inicialmente, na imprensa teuto-brasileira, sendo posteriormente agrupadas em dois volumes com o título Eines Brasilianers Lied (o primeiro publicado em Porto Alegre, em 1897, e o segundo em Berlim, em 1910).

Outro escritor bastante festejado é Paul Aldinger, pastor evangélicoluterano que chegou em 1901 na colônia Hansa-Hammonia (atual município de Ibirama, Vale do Itajaí) na condição de imigrante/colono. Ele próprio intitulou-se Ansiedler (colono), mas na prática exerceu atividades pastorais

${ }^{11}$ É importante lembrar que vários alemães e teuto-brasileiros participaram da instalação de linhas telegráficas no território brasileiro, entre eles o agrimensor Emil Odebrecht (que trabalhou muitos anos na exploração e demarcação de terras na colônia de Blumenau), o engenheiro Augusto Zittlow (que também viveu em Blumenau) e o próprio Ernesto Niemeyer, que foi auxiliar do engenheiro Guilherme Schüch, antes de assumir o escritório telegráfico em Curitiba. 
e de ensino. Foi o primeiro pastor evangélico e professor daquela colônia, fundada em 1897 pela Sociedade Colonizadora Hanseática, empresa que deu continuidade ao povoamento do alto Vale do Itajaí sucedendo a Sociedade Colonizadora de 1849 em Hamburgo. Tinha formação teológica e, na Alemanha, havia sido dirigente da Hauptvereins für deutscher Ansiedler und Auswanderer - uma das muitas associações que davam orientação e auxílio a emigrantes. Autor de crônicas e poesias, ficou mais conhecido por sua produção de natureza historiográfica escrita na lógica da germanidade e dentro dos parâmetros da deustche Mitarbeit ${ }^{12}$ (isto é, a contribuição dos imigrantes alemães ao desenvolvimento do país). Aldinger retornou à Alemanha em 1926, abandonando, assim, a experiência da Kolonistenleben (vida de colono), fundamento de muitos dos seus escritos.

José Deeke, um engenheiro nascido em Blumenau em 1875, também esteve vinculado à colônia Hansa-Hammonia, pois foi diretor da Sociedade Colonizadora Hanseática durante muitos anos e é autor de um livro que trata da implantação daquela experiência de assentamentos coloniais. Escreveu outros livros sobre o vale do Itajaí e colaborou, como cronista e poeta, nas publicações periódicas (jornais e Kalender). Era casado com Emma Deeke, nascida em Blumenau, em 1875, também escritora, autora de contos, crônicas e romances cujo tema é a vida cotidiana dos colonos. O pai de Emma, Karl Richbieter, estabeleceu-se em Blumenau no início da colonização como mestre cervejeiro e proprietário de uma cervejaria; pertencia à pequena burguesia local. A carreira de escritora começou após uma viagem realizada com os pais para conhecer a "velha pátria" Alemanha.

A mais conhecida das autoras teuto-brasileiras foi Gertrud GrossHering. Nasceu na Alemanha em 1879 e chegou com os pais a Blumenau em 1880; seu pai, Hermann Hering, tornou-se, junto com o irmão, um dos mais prósperos industriais da região. Os Hering não eram imigrantes comuns e não vieram para Blumenau como aspirantes a um lote colonial: pertenciam à pequena burguesia alemã e começaram sua vida como comerciantes e

${ }^{12}$ Este é o foco da maioria dos escritos sobre a história da colonização no período anterior à Segunda Guerra Mundial. No caso de Aldinger, o próprio imperador Pedro II, por ser "filho de mãe teuta", é caso exemplar de teuto-brasilidade. No entanto, a mesma interpretação sobre o imperador aparece em textos mais recentes, caso do livo de Oberacker Junior (1968, p. 289), que o considera "o maior dos brasileiros", usando o mesmo argumento da origem (germânica) materna. 
depois industriais. Como outras famílias abonadas da "colônia”, recebiam livros e revistas da Alemanha e tinham o gosto pela literatura, teatro e música - o que certamente explica a existência de um teatro numa Stadtplatz mais próxima de uma conformação aldeã do que citadina, onde Gertrud Gross Hering teve suas peças encenadas. Autora de contos e romances publicados inicialmente em jornais como o Der Urwaldsbote (que pertencia a seu tio, G. Arthur Koehler) e o Brasil Post (de São Paulo), sua obra mais conhecida é o romance Durch Irrtum zur Wahrheit (Através de erros à verdade), de 1913. A maior parte das publicações ocorreu antes de 1939, mas editou alguns romances na década de 1950 (faleceu em 1968). Como no caso dos demais escritores teuto-brasileiros, o principal universo ficcional é a "colônia".

No entanto, uma das paladinas da teuto-brasilidade, concentrada no binômio paisagem brasileira-cultura alemã, cuja obra poética está presente nos Kalender e, especialmente, no volume comemorativo do centenário da imigração alemã em Santa Catarina, editado por Entres (1929), não tem “raízes” coloniais. Trata-se de Maria Kahle, nascida na Alemanha em 1891: chegou ao Brasil em 1913 e, durante a Primeira Guerra Mundial dedicouse ao esforço de guerra, fazendo conferências pelas "colônias alemãs". Nesse processo, fixou-se por alguns períodos em Blumenau, retornando depois para a Alemanha. Vários volumes contendo suas poesias foram publicados no Brasil - Liebe und Heimat (1916), Deutsche Worte ([s.d.]), etc. É uma poesia grandiloqüente em relação à paisagem brasileira, aos resultados da colonização alemã e à germanidade. Na década de 1930 vários dos seus escritos, inclusive poemas dedicados a Adolf Hitler, surgiram no almanaque Volk und Heimat, editado em São Paulo pelo partido nazista. Seu nome não aparece na lista de autores do texto de Kuder (1936/37), possivelmente por não reconhecê-la como teuto-brasileira.

Nessas rápidas referências aos autores devem ser incluídos também Wolfgang Ammon, Georg Knoll, Rudolf Damm, August Schnitzler, Elly Herkenhoff e Victor Schleiff. Nascido na Alemanha em 1869, Ammon emigrou para o Brasil em 1886, estabelecendo-se como comerciante em Joinville, onde também foi presidente da Schulverein (associação escolar); em 1920 mudou-se para São Bento do Sul, outra "colônia alemã" em terras catarinenses, para dedicar-se à atividade de escritor. Colaborador de almanaques e jornais em língua alemã no Brasil e na Argentina, escreveu 
principalmente novelas e crônicas centradas nos ideais da germanidade e na vida cotidinana colonial. Knoll também era imigrante (nasceu em 1861 em Frankfurt), filho de um professor, profissão que também exerceu algum tempo no Brasil. Sua vida era a de um viandante (Wanderer): além de escritor foi colono, professor municipal, advogado e, finalmente, procurador do Estado de Santa Catarina - vivendo em muitos lugares, inclusive em Blumenau. Poeta e cronista, publicou em jornais como o Blumenauer Zeitung e o Kolonie Zeitung, e em vários Kalender. Rudolf Damm, outro imigrante da primeira geração (nasceu em Dresden, 1858), traduziu poemas de autores brasileiros para o alemão, publicados em almanaques; formou-se professor na Alemanha e depois exerceu a profissão como tradutor, produziu poemas e crônicas articulando germanidade e colonização. Augusto Schnitzler foi outro autor influente, pois trabalhou como professor primário em diversas colônias, estabelecendo-se a partir de 1873 (até sua morte, em 1918) na antiga colônia de São Pedro de Alcântara, onde possuía uma escola com internato. Nasceu na Alemanha em 1842, emigrando para o Brasil em 1860. Seus escritos, especialmente a poesia, faziam o elogio da vida colonial (na "selva") e dos valores camponeses (Bauerntum). O jornalista Victor Schleiff tornou-se imigrante em 1920 (portanto, veio para Santa Catarina durante a crise econômica da República de Weimar), aos 50 anos de idade. Após rápida passagem por Curitiba, onde foi diretor de uma escola alemã, fixou-se em Blumenau, assumindo a direção do jornal Der Urwaldsbote o mais popular do Vale do Itajaí. A exceção, nesse conjunto de autores, é Elly Herkenhoff, nascida em Joinville em 1906. Durante a Segunda Guerra Mundial viveu no Rio de Janeiro, e depois em São Paulo, exercendo a função de tradutora, retornando à sua cidade natal na década de 1960 . Desde 1921 publicou contos e poemas em língua alemã em jornais e periódicos, e tem amplo trabalho historiográfico sobre Joinville, onde ajudou a organizar o Arquivo Municipal.

Estes são os autores mais importantes, mas existem outros que viveram nas áreas coloniais de Santa Catarina. ${ }^{13}$ É o caso dos imigrantes Hugo Gensch, médico radicado em Blumenau, que publicou romances (em partes)

13 O número de escritores teuto-brasileiros é bem mais significativo no Rio Grande do Sul; estavam radicados principalmente em Porto Alegre e São Leopoldo. A lista de Kuder (1936/ 37, p. 457-465) inclui trinta nomes. As duas cidades concentravam algumas das mais importantes editoras teuto-brasileiras; algumas sobreviveram à campanha de nacionalização.

Horizontes Antropológicos, Porto Alegre, ano 10, n. 22, p. 149-197, jul./dez. 2004 
no jornal Blumenau Zeitung; Karl Kleine, professor e colaborador dos almanaques como novelista; Adolf Ringwald, comerciante, escreveu poesias e novelas para os almanaques; A. W. Sellin, diretor de colônia vinculado à Sociedade Colonizadora Hanseática, etc.; do casal Stutzer (Gustav e Therese), que residiram em Blumenau durante duas décadas, até o retorno à Alemanha - ela escreveu romances e ele relatos de viagem e textos não ficcionais sobre a colonização, publicados na Alemanha. ${ }^{14}$

Esses dados, apresentados de forma abreviada, mostram que a maioria dos autores citados nasceu na Alemanha, emigrando em idade adulta (a única exceção é Gertrud Gross Hering). No conjunto, são imigrantes ou filhos de imigrantes, embora a colonização alemã em Santa Catarina remonte a 1829 (ano da fundação de São Pedro de Alcântara). Nenhum deles se enquadra na categoria colono tal como definida na legislação imigratória brasileira - isto é, não se dedicaram ao trabalho agrícola em lote colonial; suas atividades estavam articuladas à Stadtplatz. Colonos eram os seus personagens. Entre eles são identificados professores (primários), pastores, comerciantes, jornalistas, engenheiros, diretores de colônias, profissionais liberais, servidores públicos; as mulheres, por outro lado, são donas de casa cultas, que receberam um tipo de educação caseira mais elaborada do que se poderia esperar nas escolas primárias, "alemãs” ou públicas, das regiões coloniais, e só eventualmente (caso de Elly Herkenhoff) exerceram atividades fora do lar. ${ }^{15}$ Homens e mulheres atuaram nas associações e figuram como lideranças no domínio cultural, que também aparece em âmbito privado e mais exclusivo, conforme assinalaram, de forma mais ou menos laudatória, Kormann (1994) e Renaux (1995). A dedicação à Kultur fica mais evidente na criação e funcionamento do teatro Frohsin, que contava com elenco amador formado por membros da elite urbana local, e recebia companhias de teatro alemãs, atraindo para Blumenau gente de toda a região. Ali também eram encenadas peças de autores teuto-brasileiros. A dimensão particular dessa atividade é assimilada

\footnotetext{
14 Não é fácil obter dados mais completos sobre essas pessoas e nem o artigo comporta um aprofundamento biográfico. As informações estão esparsas em algumas publicações comemorativas, inclusive no volume do centenário da imigração organizado por Entres (1929), no trabalho de Kuder (1936/37) e, intermitentemente, na revista local Blumenau em Cadernos.

${ }^{15}$ Em análise voltada para o papel da mulher no Vale do Itajaí, Renaux (1995) destaca as funções propriamente domésticas e a cultivação de valores burgueses no âmbito da camada mais alta da sociedade colonial.
}

Horizontes Antropológicos, Porto Alegre, ano 10, n. 22, p. 149-197, jul./dez. 2004 
por Renaux (1995, p. 157): a casa onde residiu Gertrud Gross Hering possuía um palco para apresentações teatrais e musicais; depoimentos memoralísticos também assinalam essas atividades nos salões domésticos de forma improvisada e vinculações germânicas.

Não deixa de ser surpreendente a criação de um teatro num lugarejo pouco maior que uma aldeia camponesa (a sede da colônia), e cuja população urbana só ultrapassou os 20 mil habitantes já na década de 1920. Como assinalou Kormann (1994, p. 31), o teatro e a associação dos atiradores iniciaram suas atividades quando havia na colônia apenas 749 habitantes. A história local atribui a uma mulher, Roese Gaertner - nascida na Alemanha em 1842 e casada, na colônia, com Victor Gaertner, sobrinho de Hermann Blumenau - a consolidação e o financiamento do teatro, com apoio de algumas famílias que se destacaram em atividades comerciais e industriais. No entanto, as atividades culturais eram bastante expressivas nas associações, dando-se certa ênfase às Gesangvereine, dedicadas às atividades musicais e literárias. De um modo geral, em todas as regiões coloniais, até mesmo aquelas associações cujas denominações apontam para práticas esportivas e recreativas (Turnverein e Schützenverein) costumavam transformar seus salões em teatros, e congregavam grupos de músicos e cantores amadores.

Nessa estruturação de indivíduos e famílias em torno de ações associativas concernentes à uma dada expressão de "alta cultura”, percebese a mobilidade social ascendente de um segmento da sociedade colonial, com perspectivas integrativas em relação à sociedade brasileira dados os seus interesses econômicos e políticos, mas que procura acentuar as diferenças atinentes à etnicidade. Estamos diante da ação coletiva de um grupo de status que procura estabelecer um estilo de vida especificamente local, articulado à noção de germanidade (Deutschtum) e, portanto, distinto da sociedade envolvente. Interesses coletivos e pertencimentos primordiais, aqui, estimulam a construção social da identidade diferenciada a partir da vida cotidiana na "colônia”, da cultura e daquilo que Weber (1991) chamou de "crença subjetiva na origem comum étnica", ${ }^{16}$ e que aparece na forma

16 Max Weber (1991, p. 268-273) procurou configurar a comunidade étnica a partir da noção de status (Stand), e suas implicações na ação política coletiva. Fatores políticos, memória histórica, habitus e sentimentos vinculados à idéia de origem (étnica) comum seriam os fatores principais na construção (social) de senso comum de pertencimento comunitário.

Horizontes Antropológicos, Porto Alegre, ano 10, n. 22, p. 149-197, jul./dez. 2004 
escrita amoldada na literatura teuto-brasileira. Os escritores integraram o grupo de status mais alto, pertencendo ou não às famílias que ascenderam socialmente, e interagindo (ainda que, em alguns casos, temporariamente) nos salões particulares e das associações. Seus escritos são versões simbólicas da estruturação da "comunidade étnica" num formato teutobrasileiro - o conteúdo cultural da etnicidade figurando como marcador identitário da fronteira com a sociedade nacional. Nesse sentido, a literatura não deve ser pensada apenas pela lógica da ambivalência (o indivíduo entre duas cultuaras), conforme assinalado por Willems $(1940,1980)$ e Huber (1979, 1993, 2002, 2003).

IV

Histórias locais (formando um painel sobre a colonização) e poesia, dando feitio à diferenciação étnica, aparecem lado a lado no volume comemorativo do centenário da imigração alemã em Santa Catarina. O Gedenkbuch zur Jahrhundertfeier Deutscher Einwanderung in Santa Catharina, editado em 1929 por Gottfried Entres, proprietário de uma livraria e tipografia em Florianópolis, contém dados biográficos sobre os deutschen Volksgenossen (compatriotas alemães) que se distinguiram no comércio, indústria, política, ${ }^{17}$ literatura e outras atividades denotativas de ascensão social e prestígio, além de artigos sobre o sistema escolar (escola “alemã”), as associações, etc. À parte todo o conjunto de dados que aparecem sob a rubrica de Brasildeutschtum usado pelo editor para, num pequeno artigo, apresentar o "progresso" resultante do "trabalho alemão" (articulado à germanidade), interessa observar a versão poética desse pertencimento a partir de alguns versos intercalados entre informações históricas ou biográficas. Trata-se de um outro aspecto da germanidade "abrasileirada", despegada dos referentes mais estritamente instrumentais privilegiados na escrita histórica, e carregada de significados identitários aproximados ao Romantismo alemão.

Os poemas que aparecem em contraposição antes do sumário são

17 Na época em que foi festejado o centenário da imigração o Estado de Santa Catarina era governado por Adolpho Konder, e seu irmão Victor era ministro da Viação - ambos teutobrasileiros e ligados ao Vale do Itajaí. Várias carreiras políticas começaram na região no início da República. 
complementares nos seus indicadores de uma identidade teuto-brasileira. O primeiro deles, de Egmont Baltz, intitulado An Brasilien, foi transcrito do volume comemorativo do centenário da imigração alemã no Rio Grande do Sul - Hundert Jahre Deutschtum in Rio Grande do Sul (1924). Os versos destacam sobretudo a paisagem, de forma grandiloqüente: o Brasil é a terra do sol, possui belos bosques de palmeiras, campinas sempre verdes, noites estreladas, colibris; a isso juntam-se certos simbolismos próximos do discurso romântico referidos à morte, como a referência ao túmulo na terra brasileira, sob a lua prateada, etc. Não há menção à Alemanha; de fato, essa forma poética diz respeito ao destino do imigrante, sua integração à nova pátria em sentido de pertencimento territorializado.

O segundo poema é assinado por Paul Aldinger - O Deutschland, herrliches Vaterland (Alemanha, magnífica pátria). Aqui, a imigração é apresentada em sentido amplo, algo como uma tarefa para pioneiros da cultura alemã que jamais deixarão de honrar e amar a pátria distante. Louva-se a vinculação ao povo (Volk) alemão e a simbólica da lealdade na diáspora contém o lema da honra pátria. O Brasil não aparece; a orientação do texto é diaspórica - o emigrante, metaforicamente, está no mundo (in die weite Welt), conforme um dos versos. Como em outros tipos de discurso sobre a teuto-brasilidade, aparecem certas palavras-chave: Treue (lealdade), Segen (prosperidade), Ehre (honra), Liebe (amor), deutsche Kultur (cultura alemã), Kampf (luta), Volk (povo) - nesse caso, atinentes à união com a “terra pátria” (Alemanha).

Apesar das aparências, os dois poemas não estão em nichos separados. Mostram-se em equilíbrio, sopesados para indicar as duas faces do pertencimento teuto-brasileiro, antecedidos pela transcrição de duas frases do Visconde de Taunay, retiradas de uma carta a um amigo publicada no jornal Blumenauer Zeitung de 3 de maio de 1884, cujo enunciado é por si mesmo significativo porque sujeito a interpretação: "A colonização alemã, para mim, é a melhor, debaixo de muitíssimos pontos de vista. Com ela é que desejo formar o fundo da nacionalidade brasileira."

$\mathrm{Na}$ época em que Taunay escreveu essas linhas o governo imperial ainda mostrava interesse na imigração alemã, tendo aprovado vários contratos com empresas colonizadoras para introduzir colonos no Vale do Itajaí e áreas próximas. Certamente o dito foi interpretado de forma equivocada em relação ao nacionalismo, num momento histórico nada favorável às diferenças culturais produzidas pela imigração. Na década de 
1930, até mesmo os conteúdos dos volumes comemorativos, como o Gedenkbuch editado por Entres (1929), receberam fortes críticas dos nacionalistas por seu apelo de natureza étnica, trazendo de volta o pressuposto do "perigo alemão" (dessa vez associado ao nazismo). ${ }^{18}$ As estatísticas de entradas de alemães no Brasil na década de 1920 aproximadamente 75 mil indivíduos, cerca de 1/3 do total desde 1824 (cf. Carneiro, 1950, tabela) - eram vistas com preocupação por ser um grupo considerado etnicamente "enquistado" e contrário à assimilação. Esta, por sua vez, fica evidente na integração política de boa parte da elite teutobrasileira que, ao mesmo tempo, patrocina uma forma de diferença cultural que tem na literatura um dos seus ícones de louvor à colonização. Isso mostra que, à revelia dos pressupostos conceituais vigentes nas décadas de 1930/40, e que influenciaram Willems, assimilação e etnicidade não são processos sociais mutuamente exclusivos ou incompatíveis! A teutobrasilidade, assim, permitiu incluir no volume comemorativo a cantata Brasil, de Olavo Bilac, numa tradução para o alemão de Rudolf Damm (Entres, 1929, p. 10-14), um dos poetas mais atentos aos valores coloniais.

A colonização e seus protagonistas são os principais assuntos da literatura em prosa e verso, figurando em destaque os termos que evocam a imigração e o processo de povoamento em regiões de floresta: Pioniere (pioneiros), deutsche Siedler (colono alemão) e seus sinônimos deutscher Kolonist ou Urwaldsiedler, Kolonie (colônia), Urwaldhaus (casa na floresta), Einwanderer (imigrantes), etc.

Olhando a ordem desses assuntos tratados no Gedenkbuch é interessante observar que o primeiro poema dedicado aos imigrantes pioneiros está situado logo após um artigo de José Deeke sobre a história da primeira fase da colonização e a fundação de Blumenau que, por sua vez, é antecedido por artigos que tratam da formação histórica de Santa Catarina e dos Ureinwohner (isto é, os indígenas). É, pois, quase um marco civilizatório. O poema, intitulado Die Pioniere, escrito por Rudolf Damm, faz a síntese poética da colonização alemã (Entres, 1929, p. 45). A referência inicial vai para os leais homens alemães (Treudeutsche Männer) que migraram das Terras do Norte, em vagas, para aqui construir cabanas

18 No período anterior à Primeira Guerra Mundial essa idéia de “perigo” apontava para a possibilidade de secessão patrocinada pelos imigrantes apoiados pelo governo imperial alemão. Sobre essa discussão, ver Gertz (1991) e Seyferth (1994). 
silenciosas, literalmente, de mãos armadas (waffenkundiger Hand) com machados e serras para trabalhar a terra:

Einst kamen auf schwellenden Wagen

Fernher aus Nordlands Gau'n

Treudeutsche Männer gezogen,

Hier stille Hütten zu bau'n

Nicht schwingen sie eherne Degen

Mit waffenkundiger Hand;

Sie dringen mit Beilen und Sägen

Und Schaufeln kühn in das Land.

Segue o poeta na descrição metafórica do desbravamento da floresta, cujo produto final são estradas, caminhos, pontes, veredas, campos que frutificam, pequenas cidades, etc., e, no final, vem a ênfase na pertinência étnica - tudo é construído no novo meio verdejante por "bons alemães" que lutaram como guerreiros corajosos em lealdade à pátria. Na parte final, o descanso (dos pioneiros) na paz sepulcral, e sua lição:

Wir sind gut deutsch geblieben

Und bleiben's auch immerdar.

Resumindo o argumento central do poema, os descendentes devem permanecer alemães para sempre, e as conquistas dos pioneiros derivam dessa condição étnica.

Os versos de Maria Kahle - Der deutsche Siedler in Sta. Catharina (Entres, 1929, p. 49) - vão na mesma direção. De novo louva-se o trabalho alemão, o colono que constrói sua casa com as próprias mãos, inclusive os móveis, ergue celeiros no quintal, possui jardim cheio de flores; o mel dourado, o pão no armário e outras referências que apontam para a Wohnkultur (cultura doméstica), enquanto indicadora de uma condição étnica (da qual também falam alguns brasileiros que escreveram sobre o Vale do Itajaí ${ }^{19}$ ). Enfim, nos termos de Kahle, o colono tira sua força no embate com a floresta, e o poema traça o percurso pioneiro até chegar à

19 Ver, por exemplo, a história do Vale do Itajaí escrita por D’Amaral (1950).

Horizontes Antropológicos, Porto Alegre, ano 10, n. 22, p. 149-197, jul./dez. 2004 
moradia (lar) definitiva, que substitui o rancho precário, cercada de um jardim de roseiras. Nos versos finais, algo semelhante ao escrito de Damm - na nova situação deve florescer o valor e a índole alemã (e aí a poetisa apela para Deus e a lealdade materna para que isso se concretize, e que as preces se façam em palavras e canções alemãs).

Hilff, Herrgott, dass aufs neu der Mutter treu Gemüt, Dass deutschen Wesens Wert in allen Herzen blüht, Und dass sie deutsch in Wort un Liedern zu dir beten!

Num outro texto - S. Bento - Joinville (Entres, 1929, p. 55-56) resultado das suas viagens por Santa Catarina, mais uma vez Kahle, em 14 quadras, fala do florescimento da vida alemã na paisagem brasileira, realização dos seus Stammengenossen (companheiros da mesma origem). Segundo sua versão poética, os caminhos da floresta mostram o trabalho alemão, a vida alemã, o espírito germânico profundamente enraizado em homens e mulheres alemãs - inevitável apelo étnico para pessoas identificadas pela rubrica "deutsche Volk".

Ihr seid wie Deutschlands Krieger: stark und treu.

A figura da retórica é bem significativa, pois os colonos são comparados a guerreiros da Alemanha, fortes e leais. Na última quadra, o elogio vai para a manutenção da língua e o apelo para sustentar os elos com a velha pátria alemã. Textualmente:

Und wie der Muttersprache reines Klingen

Noch nie von Eurer Zunge ward verbannt,

Hebt Liebe auch im Herzen noch die Schwingen

$\mathrm{Zu}$ Euren alten deutschen Vaterland...

Maria Kahle escreveu poema semelhante (Entres, 1929, p. 96-97), intitulado Von Jaraguá nach Blumenau durch deutsche Siedelungen (De Jaraguá para Blumenau através de colônias alemãs), onde faz a descrição de uma viagem realizada em um domingo ensolarado, elogiando o meio alemão, a beleza da paisagem no sentido de um ambiente já civilizado onde 
se distinguem os jardins floridos, os pomares, as casas em enxaimel; destacando o dado aparentemente mais importante - o fato de, por toda parte, ter sido saudada no idioma alemão.

Outros dois trabalhos de Kahle, sobre o mesmo tema da colonização, foram transcritos no Gedenkbuch (Entres, 1929, p. 86, 259). Em Urwaldsiedler (colono na selva) temos mais uma vez o apelo à preservação dos valores germânicos. Basicamente, o poema fala de Heimweh (saudade), nostalgia das terras do Norte (= Alemanha), presente na lembrança dos colonos. Algumas partes são bastante enfáticas como expressão dos valores primordiais relacionados à etnia.

[...]

Wir konnten alles verpfflanzen heimatlich in dies Land, Aber wir haben die Rätsel des Ursprungs nicht gekannt.

Fülle gab uns die Erde, der unser Mühen front, Wir haben der neuen Heimat mit Dank und Treue gelohnt.

Aber zur Weihnacht, wenn Sommer hell auf den Staaten glüht, Zihen verschollene Lieder plötzlich durch unser Gemüt.

Nordlands Tannenwälder rauschen in unsern Traum,

Da wird uns Deutschland ein grosser prangender Lichterbaum, [...]

Unsere Kinder werden das Heimweh nie erfahren, Sie sind Besitzer und Erben, wo wir noch Wanderer waren.

Aber die Nordlandserde ist auch in ihrem Blut, Und das Weistum alter Geschlechter in ihrem Wesen ruht.

Sie sollen der neuen Heimat Liebe und Treue weihn Aber in Wesenstiefen werden sie Deutsche sein. $[\ldots]$

Basicamente na primeira pessoa do plural (portanto, englobando os colonos estabelecidos na floresta, conforme o título), diz a poetisa: podemos 
plantar patrioticamente nessa terra (= Brasil), mas não somos versados no enigma da origem; a terra nos dá abundância advinda do nosso trabalho e nós recompensamos a nova pátria com agradecimento e lealdade; mas por ocasião do Natal, quando o verão ilumina incandescente a sementeira, surgem na nossa alma as canções desaparecidas; os bosques de pinheiros das terras do Norte surgem nos nossos sonhos, e para nós a Alemanha torna-se uma árvore iluminada; nossas crianças jamais saberão o que é saudade, elas são proprietárias e herdeiras onde nós somos ainda peregrinos; mas a terra do Norte está igualmente no seu sangue, e a sabedoria da velha linhagem repousa em seu ser; elas devem dedicar seu amor à nova pátria, mas no âmago do seu ser são alemãs. Outras partes desse texto evocam a infância dos imigrantes, a árvore de natal, os céus da Alemanha, até a afirmação final, primordialíssima: ainda que os filhos nunca tenham a oportunidade de ver a velha pátria, existe uma Seelenheimat (pátria da alma) que abrange todo o povo alemão.

Os versos distinguem a primeira e a segunda geração no Brasil, simbolicamente usando o recorte da saudade e de lembrança, mas incluem todos na mesma origem Volk e na mesma cultura compartilhada na "nova pátria”, à qual devem lealdade. Os mesmos temas atravessados pela noção de Heimweh (saudade) estão em outro poema relativo aos colonos - Der alte Siedler in Brasilien (O velho colono no Brasil). Mais uma vez entra em cena a nova terra, com menção ao canto do sabiá que anuncia a morte de um velho colono, o qual solicita a um jovem seja colocado sobre sua mortalha o Gesangbuch, pois esse livro de canções alemãs foi por ele honrado. As implicações da germanidade são claras no texto como nessa passagem:

Dies deutsche Liederbuch, ich hielt's in Ehren, Und eins nur will ich noch von Gott begehren:

Dass unser Blut nicht fruchtlos hier vergeht

Dass deutsch ihr bleibt in Liedern und Gebet.

O colono, portanto, guardou com honra o seu livro de canções e pede a Deus que o sangue (alemão) não se torne estéril e que todos permaneçam alemães em canções e rezas. São palavras dirigidas à segunda geração (os jovens) com recado explícito: Heimweh está no sangue, é a saudade da 
pátria situada no hemisfério Norte, contida no íntimo daqueles que vivem na terra do futuro (o Brasil). A metáfora de sangue é usada para definir a índole ou caráter (Wesen) germânico como algo inato, próprio do Volk, à qual acrescenta o dado mais concreto da linguagem, conclamando todos a usar a língua materna, sinal distintivo que marcou os discursos étnicos nas décadas de 1920 e 1930, diante da ameaça de nacionalização do ensino.

A poesia de Maria Kahle é bastante precisa na sua aparente dualidade. A germanidade, a cultura alemã, vem em primeiro lugar, ainda que diferenciada em terras brasileiras. Por isso, sua visibilidade no Gedenkbuch é bastante significativa. Por outro lado, a colonização e, principalmente, o trabalho pioneiro, têm destaque nos versos de outros autores, o que remete à idéia de uma nova pátria construída no Brasil, o país de acolhida apresentado como “o novo”. É o caso de um texto de Paul Aldinger - Nun singt dem neuen Heimatland (Agora cantamos a nova terra pátria), também incluído no Gedenkbuch (Entres, 1929, p. 253), que apresenta a forma mais freqüente assumida pela nova identidade dupla:

Nun singt dem neuen Heimatland

Brasilien zu Ehren,

Wir Wollen ihm mit Herz und Hand

In Zukunft angehören

Du alte Heimat lebe wohl!

Wir denken dein in treue

Und bringen unsres Fleisses Zoll

Brasilien dir, du neue!

$\mathrm{O}$, möchte doch ein freundlich Band

Um beide stets sich schlingen,

Dem alt'und neuen Vaterland

Ein Lebehoch wir bringen.

Aí está bem presente a ambivalência (em sentido etimológico de algo que apresenta dois valores ou dois aspectos opostos) assinalado por Willems e depois por Huber. Na verdade, essa expressão escrita de pertencimento procura conciliar elementos aparentemente conflitantes ou opostos numa 
única categoria. Nos seus versos Aldinger chama seus camaradas para “cantar” a nova pátria (Heimatland), honrar o Brasil, país ao qual querem pertencer, com coração e mãos, no futuro. Dá adeus à velha pátria, pensando nela com lealdade, trazendo o tributo diligente (dos imigrantes) para o Brasil, o novo. Não obstante, na última quadra expressa o desejo de um vínculo amigável permanente entrelaçando as duas pátrias. De fato, não há oposição, e isso se manifesta no uso inicial do termo Heimatland - uma referência a lar e território que, conjugados, são a pátria. O termo novo, por sua vez, tem suas ambigüidades - pode estar referido a algo recente, acabado de fazer, com pouco tempo de existência, ou ter o sentido de novidade. Juntando os dois termos - Heimatland e neue - na sua dimensão mais restrita, podem indicar, simplesmente, a colonização alemã. O discurso étnico metaforizado na poesia teuto-brasileira fala da construção de uma nova pátria no Brasil, o que, por sua vez, o transforma em nova Vaterland. O uso alternado (ou diferenciado) dessas duas palavras, que em português convertem-se em uma só (pátria), permite jogar com diferentes elementos de identificação, abrangendo a nova vida em terras brasileiras. O novo, afinal, começa numa cabana no meio da floresta - o imigrante no meio da natureza, como registrou Ernesto Niemeyer na forma poética. Em Die erste Hütte (A primeira cabana), transcrita em Entres (1929, p. 250-251) - parte de uma obra maior intitulada Teuton (eines Brasilianers Lied), publicada em Porto Alegre em 1897 - emerge a natureza selvagem com seus animais, torrentes d'água, árvores envoltas em milhares de cipós - e nesse "deserto" (Wildnis) vai ser construída a primeira cabana - "glücklichem Beginnen” (feliz começo), sem dúvida um marco civilizatório. A imagem de um deserto florestal aparece em outras narrativas sobre a colonização, como já mostrei em outro trabalho (Seyferth, 2000), evocando a supremacia da cultura frente à natureza hostil (mas também maravilhosa na poética de Niemeyer) que deve ser domada.

Isso é o novo - a colonização - claramente definido em outros versos do mesmo autor que lembra aos teuto-brasileiros sua origem/sangue alemão e a necessidade de serem bons cidadãos brasileiros sem abandonar a índole, o caráter germânico de diligência, lealdade, dever e ordem. Conforme assinala entre os versos de Den Deutschen in der Fremde (os alemães no estrangeiro), publicados no Kalender für die Deutschen in Brasilien, em 1938: 
Verehrt die Pflicht, die Ordnung liebt,

Baut deutsches Heim aufs Neue.

Literalmente, os teuto-brasileiros devem venerar o dever e amar a disciplina construindo um lar alemão no novo (país). O mesmo princípio do sangue como qualificador do Volk presente nos versos de Maria Kahle aparece em poemas de Niemeyer publicados na década de 1930 - caso do acima citado, onde os "alemães" são instados a lembrar do seu sangue. Em Des Siedlers Lied (A canção dos colonos), publicada no almanaque de orientação nazista Volk und Heimat, em 1938, fala do imigrante que deixa seu país por razões econômicas para se estabelecer como colono no Brasil, onde é rei na sua própria lareira (referência à casa, aos campos plantados, enfim à parcela de terra denominada colônia); portanto, na nova terra obteve o que não havia conseguido na velha pátria que, não obstante, continua a amar e honrar. E completa:

Und uns're Jugend ehrt das Blut,

Das in den Adern rollt...

Nessa linguagem racializada, a juventude (teuto-brasileira) honra o sangue que corre nas suas artérias. De certa forma, está assinalada aí a noção de um Volksgruppe diferenciado no território brasileiro, referendada numa crônica bastante conhecida de Niemeyer, com o título de Teutonem Literatur, publicada no Kalender für die Deutschen in Brasilien, em 1917. Ali fala da necessidade dos teuto-brasileiros possuírem uma literatura própria e ao mesmo tempo define uma identidade específica: no núcleo, alemã, mas também brasileira. Reivindica, então, o direito de usar a língua alemã no cotidiano, podendo saudar o Brasil não necessariamente em português. O teuto-brasileiro, segundo seus termos, herdou dos antepassados seu espírito germânico, deve honrar seu sangue, seus costumes, sua língua. Por outro lado, nem a literatura brasileira, nem a alemã, dão conta da realidade teutobrasileira; e, fazendo menção específica à poesia, diz que os poetas da Alemanha escrevem sobre outra realidade, nada sabem da "nossa terra", falam de outras plantas, outras montanhas, outro céu, desconhecem a vida nova dos teutos no Brasil. Fica, assim, assinalada a diferença cultural produzida pela imigração em terras brasileiras, distanciada da realidade 
social da velha pátria, bem como da sociedade abrangente.

A fronteira simbólica, portanto, é a saga do povoamento, ou a conquista da floresta pelo colono, que pode assumir contornos inusitados. É o caso dos versos de Rudolf Damm, Willkommengruss des Kreuzers "Von der Tann" (Saudação de boas-vindas ao cruzador "Von den Tann”), reproduzidos em Entres (1929, p. 257), onde é feito um paralelo entre um navio de guerra (cruzador) que deixa a Alemanha conduzindo a bandeira imperial cruzando os mares e a emigração: os imigrantes também lutam, uma luta com a natureza, trabalho pesado para construir um lar. Por um lado, o poeta está se referindo aos que lutam pela pátria e pelo imperador, por outro, aos colonos que precisaram deixar a pátria e estão lutando pelos costumes, pela língua materna, pela germanidade. Observa-se que o discurso pode ter variações na forma, mas seu conteúdo é praticamente o mesmo em quase todos os escritos poéticos. O apelo final de Damm certamente remete à situação conflituosa vivida por imigrantes e descendentes durante a Primeira Guerra Mundial: ${ }^{20}$

Wir reden deutsch mit unser Gott

Und deutsch mit unsern Kindern,

Und lassen uns durch Hohn un Spott

Nicht unser Deutschtum mindern.

Temos nesse texto o poeta reafirmando que os teuto-brasileiros falam alemão com seu Deus, com seus filhos, e sua germanidade não deve ser esquecida por causa de ironia e escárnio. Reflete o início de um período conflituoso, que culminou com a intervenção nacionalista do Estado Novo, marcado por ameaças de intervenção no sistema escolar particular existente nas colônias, e de proibição do uso da língua alemã.

É significativa a inclusão da Canção do Exílio, de Gonçalves Dias, em tradução para o alemão realizada por Damm, junto a um poema deste autor intitulado Mein Vaterhaus (Minha casa paterna). Não se trata de paralelo em matéria de exílio associado à imigração. A Heimat (pátria) é

20 Entres (1929) não indica a publicação original da maioria dos poemas transcritos no Gedenkbuch. Pelo teor do texto, Damm provavelmente o escreveu durante a Primeira Guerra Mundial, quando as instituições comunitárias teuto-brasileiras foram ameaçadas de intervenção - o que de fato aconteceu entre 1917 e 1919. 
territorializada tanto na tradução (onde terra $=$ Heimat) como no texto sobre a casa paterna situada no contexto da floresta, cercada de laranjeiras. Os versos de Gonçalves Dias ressaltam a paisagem, com certa ênfase nas palmeiras ("Minha terra tem palmeiras", etc.) - ícone teuto-brasileiro para falar da distintividade da Urwald (floresta) brasileira em relação às "terras do Norte" (referência poética à Alemanha). Os versos de Damm falam de uma casa paterna no Brasil, enfatizando as belezas naturais que estão no seu entorno. É o lar (Heim) que, com a devida licença poética, representa a Heimat (pátria) - a terra onde vive o imigrante e seus descendentes, no caso, a “colônia”. Enfim, sua pátria íntima está no Brasil e não na Alemanha.

O tema da primeira casa construída na floresta tem relação com a idéia de desbravamento, pioneirismo, como pode ser observado, por exemplo, nos versos de Elisa Protzen, imigrante que viveu em Blumenau e depois se deslocou para o Rio Grande do Sul. Mein Urwaldhaus (Entres, 1929, p. 260) reflete a nostalgia da casa provisória construída com troncos de palmeiras, à qual a autora faz referência por diminutivos - Häuschen (casinha) e Hüttchen (pequena cabana). A casa construída por um "pioneiro" da floresta é "inesquecível" e, como em outras obras semelhantes, voltam à cena riachos, flores, brisa noturna, brilho do sol dourado da manhã, enfim, a natureza da nova pátria. Evidencia-se o duplo sentido da palavra Heimat nessa poesia - o lar na nova terra, numa outra paisagem marcada, principalmente, pelas palmeiras e pelo brilho do sol.

Mas há algo mais a demarcar a nova pátria além da imagem concreta de uma paisagem - os túmulos criam uma Heimat, um vínculo com o lugar onde estão enterrados os ascendentes. Um poema de Wilhelm Rau - autor pouco conhecido, pastor evangélico residente em Joinville - Auf der Boa Vista (Entres, 1929, p. 261), em meio a muitas referências à paisagem (palmeiras, inclusive), afirma que aqueles que lutaram com a natureza e construíram seu lar não são mais estranhos ou hóspedes da terra, pois ela tornou-se sua pátria, especialmente quando nela estão enterrados os seus pais.

Und wer in diesen harterstritt'nen Boden

Dem Vater und der Mutter grub des Grab,

Der hat ein heilig Heimatrecht erworben... 
Dito de forma simplificada, quem enterrou pai e mãe nesse solo endurecido adquiriu o sagrado direito de pátria. Mas essa noção de pátria territorialmente circunscrita tem sua contrapartida no outro hemisfério, o Norte, onde ficaram muitos familiares e amigos. Entra na cena poética o "berço" (Wiege), a saudade da terra de origem - visualizados até nos títulos de alguns poemas, como, por exemplo, Schwarzwälders Heimweh (Saudade da floresta negra) e Hüben und drüben (Por ambos os lados), ambos de Adolf Ringwald, reproduzidos no Gedenkbuch (Entres, 1929, p. 262). No primeiro é nostalgicamente evocada a infância do poeta em terras germânicas, seu berço; no segundo, o tema preponderante é o Brasil, suas campinas, montanhas, vales e rios, mas assinalando também o "outro lado", o belo e verde rio Reno onde vive sua mãe e irmão, assinalando nos últimos versos o amor ao Brasil, agora sua terra pátria (Heimatland), sem esquecer o verde Reno onde está seu berço, lugar para onde viajará mais uma vez com prazer em peregrinação aos túmulos dos heróis alemães.

Ich lieb Brasilien, jetzt mein Heimatland

Dich grüner Rhein nicht minder, wo meine Wiege stand.

Doch fahr ich einmal nüber, sei's nicht zur lust am Rhein

Zu deutschen Heldengräben, soll's eine Wallfahrt sein.

Ringwald, outro autor menos conhecido, nasceu na Alemanha em 1807, emigrou para o Brasil no início do século XX, era comerciante em Bom Retiro e colaborador de jornais e almanaques. O poema acima foi escrito em 1914, portanto, num momento difícil para os alemães no Brasil. Expressou a dupla identidade na vinculação com a nova terra e na referência ao berço (lugar de nascimento) e aos túmulos dos heróis que estão do outro lado (drüben) - a velha Alemanha.

A lógica simbólica da terra configurando a pátria é bem mais honorífica nos escritos da segunda geração, que não passou pela experiência da emigração e, como Ernesto Niemeyer, celebra em versos a paisagem brasileira, embora ela seja, freqüentemente, local (colonial!) ou regional. Um bom exemplo é a poesia de Elly Herkendorf, que fala das belezas naturais da região Norte de Santa Catarina, e da sua cidade natal, Joinville, como nestes versos reproduzidos por Walburga Hüber (2003, p. 59-60) - uma saudação à pátria mais bela do mundo, as campinas ensolaradas nas praias do Sul, as ondas, as matas murmurejantes, as cidades com ruas ensolaradas, 
etc.:

Ich grüsse dich, Heimat, ich grüsse die weiten

Durchsonnten Gefilde am südlichen Strand...

Ich grüsse die Wogen, die schäumend entgleiten,

Die rauschenden Wälder, die endlos sich infinito breiten

[...]

Ich grüsse die Städte mit Sonnigen Strassen

[...]

Ich grüsse dich, Heimat, du schönste Welt!

No entanto, textos como esse, que abordam apenas a exuberância das paisagens (inclusive urbanas), são raros, pois quase sempre existe a contrapartida da domesticação. Como já mostrei, o foco é a colonização alemã, e ela tem como pano de fundo a natureza brasileira convertida em lugar civilizado. Além de autores já citados, esse assunto aparece de forma contundente na poesia de Victor Schleiff, Georg Knoll (filho de Ida Knoll, professora e também escritora de novelas e contos, colaboradora dos Kalender) e Alfred Funke (eventual colaborador de publicações periódicas teuto-brasileiras, mais conhecido por ter publicado na Alemanha diversas obras sobre a colonização alemã e sobre o Brasil).

Funke, em Bilder aus der Kolonie (Retrato da colônia), poema publicado originalmente no Kalender für die Deutschen in Brasilien, em 1908, e reproduzido por Entres (1929, p. 67-69), fala da diáspora alemã com certo humor - portanto, o assunto dos versos iniciais é a pátria (Vaterland) de origem e a emigração até chegar à colônia e à distribuição de lotes em alguma Pikade (linha colonial ou picada), envolvendo dois imigrantes, um da Pomerânia e outro da região do Mosela, que fazem um percurso através de florestas, cursos d’água, vales e montanhas; na segunda parte, o assunto é o cotidiano colonial familiar desses indivíduos, mencionando seus filhos, felizes Pikadenknaben (meninos da picada). Não está se referindo a um paraíso tropical, mas à transformação dos imigrantes em colonos estabelecidos, usando, inclusive, palavras portuguesas germanizadas (Pikade, Mihhobrot, etc.) ${ }^{21}$ para mencionar formas de lazer e tarefas

${ }^{21}$ Entre outros autores, Willems (1980, cap. X) fez uma análise sobre o linguajar teutobrasileiro, listando mais de mil palavras portuguesas incorporadas à fala alemã rústica dos 
camponesas. O poema se encerra dizendo que mesmo tendo nascido do outro lado (drüben) - isto é, em terras alemãs - os colonos aprenderam a amar o Brasil.

Ob man auch geboren "drüben”, Lernt man so Brasilian lieben.

Knoll e Schleiff, por outro lado, mostram seu encanto com a natureza brasileira transmitindo uma imagem paradisíaca, inclusive do contexto colonial, conforme assinalou Huber (2002). Mais uma vez as palmeiras, as florestas, são as principais atrações poéticas, mas também a tranqüilidade bucólica da Canaã colonial. No entanto, o "paraíso construído", conforme interpretação dos textos feita por Huber (2002), tem conteúdo étnico relacionado ao "trabalho" e "sangue" dos colonos. Ao lado bucólico assinalado pela paisagem onde farfalham palmeiras, se ouve o sabiá, ou pelas choupanas repletas de vida, casinhas cercadas por jardins, pastos, plantações, se acrescenta alguma referência à origem alemã dos construtores do paraíso. Assim, no poema Kolonien (Colônias), após mencionar vários aspectos da paisagem natural e humana, diz Knoll: ${ }^{22}$

Da unter den Palmen hör ich traulichen Klang

Germanisches Leben, die Täler entlang.

Portanto, o som familiar que o poeta ouve entre as palmeiras é a vida germânica que viceja nos vales. Schleiff é mais direto em relação à imagem ou representação da germanidade, como podemos observar nessa parte do seu poema Alte und neue Heimat (Velha e nova pátria).

Die alte Heimat gab der neuen

Das was ein Land macht Gros und stark

Gab ihr von ihrem Blut dem treuen

Wirschufen hier mit schwiel'gen Händen

Die Wildnis um zum Paradies,

colonos. Kuder (1936/37) menciona o uso dessa linguagem na ficção escrita em língua alemã - uma das bases da crítica ao baixo valor estético da literatura teuto-brasileira.

${ }^{22}$ Os poemas de Knoll e Schleiff estão reproduzidos em Huber (2002, p. 36, 39). 
Und überall an allen Enden

Grüsst deutsch Arbeit, deustscher Fleiss.

Resumindo o argumento poético, a velha pátria deu à nova (o Brasil) aquilo que faz um país grande e forte - seu sangue, sua força, que permitiram transformar a selva em paraíso (com mãos calejadas), vicejando em toda a parte o trabalho e a dedicação alemã. Essa percepção envolvendo a noção de Deutschtum é reforçada, num outro momento, na saudação à terra dos pais (a Alemanha): nos termos de Schleiff, apesar da beleza e majestade da nova terra, da pujança e prosperidade, os corações estão presos à velha pátria; a fidelidade ou lealdade (Тreue) também pertencem à ela, mesmo no país do futuro. Em outro poema, Der ersten Einwanderer (Os primeiros imigrantes) é repetido o argumento da selva dominada pelo trabalho do imigrante; e a prosperidade vicejante da colônia é cantada no poema Blumenau - descrita como uma ilha de felicidade, mar de jardins, numa apologia civilizatória muito próxima à idéia utópica da lendária Schlaraffenland (terra da cocanha), uma vitória do imigrante obtida com muita luta e sacrifícios. De fato, a poesia está bem distante das narrativas escritas e orais dessa "luta" contra a floresta que documentam a história da colonização ou mesmo algumas novelas e contos cujo cenário são as primeiras colônias, e muito mais empenhada na construção de pertencimento nacional e étnico.

De forma menos sofisticada e numa linguagem coloquial nem sempre atenta aos cânones literários e, por isso, considerados de baixa qualidade estética e com excesso de neologismos ${ }^{23}$ (cf. Kuder, 1936/37; Willems, 1980), os romances, contos e novelas narram o percurso da migração e a vida na colônia, enfatizando o novo meio ambiente. ${ }^{24}$ Seus personagens são,

${ }^{23}$ A formação de uma linguagem própria nas "colônias alemãs" - Sprachmischung (língua mista, aculturada) - não mereceu muitos estudos apesar da sua importância lingüística. Destacamse trabalhos mais antigos como os de Schappelle (1917), Fausel (1959) e Willems (1940, 1980).

24 Existe uma literatura não ficcional, constituída por narrativas históricas e textos memorialísticos, que trata dos mesmos temas. Nas duas últimas décadas tem despertado o interesse de descendentes e de pesquisadores, o que levou à publicação de alguns manuscritos inéditos, pertencentes a arquivos públicos e particulares, quase sempre em edições bilíngües. São exemplos significativos o texto de Josef Umann, Memórias de um Imigrante Boêmio (1981), e o Memorial do Pastor Wilhelm G. Lange (2003), publicado por iniciativa de alguns descendentes, contendo também um conjunto de cartas familiares, tornando público parte do conteúdo de um arquivo particular.

Horizontes Antropológicos, Porto Alegre, ano 10, n. 22, p. 149-197, jul./dez. 2004 
principalmente, colonos em sentido amplo (pois a categoria engloba os estabelecidos em linhas coloniais ou nos vilarejos, vilas e pequenas cidades emergentes nas áreas coloniais), imigrantes recém-chegados, às vezes chamados Neudeutschen (alemães-novos), e brasileiros nas situações interétnicas.

A mais importante romancista do Vale do Itajaí foi Gertrud Gross Hering; parte da sua obra foi objeto de análise na área de literatura/crítica literária, especialmente nos trabalhos de Walburga Huber $(1979,1993)$ e Lia Carmen Puff (2000), que realizou um exercício de tradução para o português do conto Ein Stiefkind der Natur (Uma enteada da natureza); e sua atuação nos meios culturais blumenauenses consta de um estudo de Maria Luiza Renaux (1995) sobre as mulheres do Vale do Itajaí. Talvez seja uma das representantes mais perfeitas do universo burguês alemão do século XIX, recriado em Blumenau na virada para o século XX: as famílias em ascensão social, com enriquecimento na atividade industrial e comercial, burilaram a tradição cultural instituída desde os tempos iniciais da colonização por Hermann Blumenau, formando pequenas bibliotecas particulares, promovendo reuniões literárias e musicais em âmbito privado e nas associações. Puff (2000, p. 12-13) assinalou que o tio de Gertrud, Bruno Hering, criou uma biblioteca na indústria têxtil que possuía com o irmão; o marido da escritora, Richard Gross, era músico amador, e seu primo, G. A. Koehler, era proprietário do jornal Der Urwaldsbote, o principal veículo de divulgação da sua produção literária. Alguns dos seus escritos, inclusive o conto traduzido por Puff, são construídos a partir dos perfis psicológicos dos personagens centrais, quase sempre mulheres imigrantes. Mas nos romances estão presentes não só as temáticas constitutivas da poesia teutobrasileira (a nova terra, a paisagem, a colonização, a noção de Heimat, etc.) mas também os conflitos internos, a vida cotidiana e a situação interétnica. Isso pode ser exemplificado pelo enredo de dois dos seus romances - por sua importância, também destacados por Huber (1979, 1993): Durch Irrtum zur Wahrheit (Através dos erros a verdade) e Aus Kinder werden Leute (Crianças tornam-se adultas), ambos publicados no jornal Der Urwaldsbote - o primeiro em 1913, o segundo em 1930-31, e depois reeditados por G. A. Koehler, proprietário do jornal e dono de uma pequena editora.

Os principais personagens do primeiro romance são dois imigrantes recém-chegados à colônia Hansa - um deles recebe uma parcela de terras (lote) na floresta, o outro se localiza como colono em área já povoada. O 
primeiro triunfa na selva; o outro, descrito com um inconformado com o modo de vida colonial, procura introduzir técnicas agrícolas modernas, entra em conflito com os povoadores mais antigos, fracassa inclusive no casamento com mulher local (teuto-brasileira). Há vários outros elementos significativos, inclusive a redenção do fracassado a partir do relacionamento com uma mulher culta (num meio inculto), que canta Wagner em plena selva. Mas o que interessa destacar nesse enredo romântico, que tem como cenário a fase final do povoamento do Vale do Itajaí, é o contraste entre os estabelecidos (teuto-brasileiros) e os Volkdeutsche recém-chegados - gente que pertence ao mesmo povo, tem a mesma “origem”, mas com estilo de vida e formação cultural distinta. São estranhos, ou mesmo estrangeiros, daí o uso de uma categoria específica para designá-los, sobretudo nos contextos urbanos: Neudeutsche. Embora no romance as atitudes "modernizantes" do alemão novo sejam apresentadas numa forma positiva, em geral as representações locais sobre eles costumam conter adjetivos de sentido desqualificador: ora são arrogantes, pretensiosos (por que se julgam "alemães” melhores), ou simplesmente ignorantes em relação ao trabalho agrícola e aos costumes da colônia.

$\mathrm{Na}$ realidade, os fluxos migratórios alemães para o Brasil numericamente mais importantes ocorreram no período que antecedeu a Primeira Guerra Mundial, e na década de 1920 durante o período da crise econômica do após-guerra. Antes da guerra, diversas famílias foram encaminhadas para as áreas de assentamento de colonos na região da colônia Hansa $^{25}$ (lugar que serve de base ao romance), onde passaram a conviver com descendentes de alemães originários de outras regiões coloniais. O estudo de Ursula Albershein (1962) sobre essa área - o atual município de Ibirama - faz menção aos alemães novos dizendo que estes demonstram sentimentos de superioridade em relação aos teuto-brasileiros. Há, de fato, um conflito de identidades, conforme mostrei em outro trabalho (Seyferth, 2002b), relacionado à posição de classe (sobretudo na década de 1920, quando os recém-chegados preferiam ficar em área urbana ocupando cargos técnicos na indústria, algo revelador de maior escolaridade, já que a população local era, majoritariamente, de colonos e operários oriundos do

25 Trata-se do núcleo administrativo da Sociedade Colonizadora Hanseática, e ponto de partida da ocupação do alto Vale do Itajaí, fundado em 1897. A empresa foi dirigida durante muitos anos por José Deeke, que, além de ficcionista, produzia livros sobre a história da região.

Horizontes Antropológicos, Porto Alegre, ano 10, n. 22, p. 149-197, jul./dez. 2004 
meio rural) e diferentes concepções sobre germanidade, pois, como se percebe na própria literatura, há a dimensão brasileira da Heimat que os recém-chegados, segundo os ditames locais, não possuíam. No romance de Hering, e na literatura teuto-brasileira em geral, faltam aos alemães-novos conhecimento e prática num meio ambiente novo, e humildade para aceitar conselhos da população local mais experiente em matéria de domar a selva.

O lado mais conflituoso dessa relação pode ser observado num conto de José Deeke (Alberto Korfel, publicado no Kalender für Deutschen in Brasilian, em 1929) que narra os problemas de adaptação de um imigrante engenheiro e sua irmã: no universo ficcional, o alemão mostra seu desprezo pela cultura teuto-brasileira, enquanto sua irmã, numa forma compensatória, procura entender e adaptar-se às peculiaridades locais. Na narrativa revelase o descompasso entre a cultura e o modo de vida próprios da pátria de origem e o ambiente sociocultural das "colônias alemãs” do Brasil. Apesar da diferença cultural e do aparente conflito entre nacionalismo alemão e etnicidade teuto-brasileira, o final é feliz, e o alemão-novo abranda sua arrogância e sentimento de superioridade para curvar-se às boas coisas da colônia.

O romance Aus Kindern werden Leute, já citado, apresenta a versão ficcional de Hering para outras facetas da vida colonial e das relações interétnicas. Simplificando essa narrativa, aí está traçada a odisséia de um jovem desde sua Tatutiefe até uma grande cidade brasileira, e seu retorno à Heimat (a “colônia alemã”). A expressão Tiefe (profundeza, abismo, fundo) é indicativa de assentamento colonial em área distante de qualquer Stadtplatz. Na linguagem coloquial teuto-brasileira usa-se a corruptela tifa, lugar mais próximo das profundezas da natureza do que da civilização. Portanto, o herói sai de uma linha colonial distante e do convívio com famílias alemãs para obter emprego em Blumenau, deslocando-se pouco depois para Santos em busca de melhores oportunidades de trabalho. Nesse percurso aprende a falar português, assume a condição de brasileiro, porém, e sobretudo, descobre-se teuto-brasileiro no contraste com a sociedade abrangente - seja em Santos, ou nas cidades por onde passou (Itajaí, onde conheceu negros e mulatos, ${ }^{26}$ e Curitiba). O círculo se completa com o

\footnotetext{
${ }^{26}$ A cidade de Itajaí, bem mais antiga, pois sua fundação remonta ao Brasil-Colônia, está situada fora da região colonizada, mas recebeu imigrantes desde o início da ocupação do Vale do Itajaí. Se no romance não é um lugar “germanizado”, paradoxalmente, produziu as principais
} 
retorno a Blumenau após o enfrentamento de uma epidemia de febre amarela em Santos, e o casamento com uma amiga de infância. Ao longo dessa trajetória, a romancista descreve a vida colonial no seu início, constrói personagens inspirados na vida real, ${ }^{27}$ põe em evidência o pertencimento à região colonizada - a Heimat em seu sentido mais íntimo e comunitário -, mas, igualmente, ao Brasil, a verdadeira Vaterland dos filhos dos imigrantes, que também devem honrar a herança germânica.

Independentemente dos dramas individuais e familiares que constituem o núcleo dessas histórias que têm como referência a imigração, os preceitos da diferenciação cultural, da identidade teuto-brasileira, enfim, da especificidade da "colônia alemã" no Brasil, estão presentes nos contos e romances de outros escritores, juntamente com a presença ubíqua da duplicidade de pátrias, acentuando, por um lado, a "nova terra”, à qual os filhos pertencem por direito de solo e, por outro, a lealdade devida à nação alemã. É impossível mencionar todos (mesmo restritos ao Vale do Itajaí e adjacências) nos limites de um artigo, mas uns poucos exemplos a mais reforçam esses argumentos.

Em Liebe und Pflicht (Amor e dever), romance publicado na íntegra no Kalender für die Deutschen in Brasilien, em 1922, Emma Deeke conta uma história cujo eixo são os dramas em torno de casamentos sem amor, onde discute, através das falas dos personagens, a boa adaptação do imigrante à nova pátria, a desilusão e desejo de retorno (nem sempre possível) do imigrante que não consegue se integrar na vida colonial e, principalmente, a necessidade de honrar as raízes germânicas (em falas referidas à Primeira Guerra Mundial) expressando formas possíveis de ajudar a "velha pátria", voltando para defendê-la ou ajudando o esforço de guerra a partir do Brasil). O significado é simples: imigrantes e descendentes são cidadãos brasileiros e amam a nova terra onde construíram uma vida nova, mas permanecem apegados à sua origem, costumes e língua materna. Nesse romance, como também nos demais, evidencia-se a distância cultural

\footnotetext{
lideranças políticas teuto-brasileiras de Santa Catarina na Primeira República - Lauro Muller, cujo pai era comerciante estabelecido na cidade, e os irmãos Konder.

27 Pelo menos dois protagonistas são pessoas cultas - uma dona de casa poetisa nas horas vagas e um professor com formação universitária estabelecidos em plena colônia. Em Blumenau, possivelmente por causa das vinculações diplomáticas e acadêmicas do fundador da colônia, havia diversas pessoas com escolaridade acima da média, aí incluídos alguns literatos, como a própria Gertrud Gross Hering.
}

Horizontes Antropológicos, Porto Alegre, ano 10, n. 22, p. 149-197, jul./dez. 2004 
entre alemães e teuto-brasileiros, quase sempre assinalada através de personagens nascidos na Alemanha que assumem uma posição de superioridade da pessoa culta, sem compreender o mundo da colônia.

Essa forma de diferenciação no âmbito da germanidade aparece mais explicitamente na obra de José Deeke, marido de Emma Deeke e assumidadmente teuto-brasileiro. No conto Um das Brasil - Deutschtum, publicado no Kalender für die Deutschen in Brasilien, em 1932, expõe o conflito através da fala de dois alemães que expressam sua crença na inferioridade cultural dos teuto-brasileiros e são devidamente contestados por um teuto-brasileiro "consciente" e "culto". Juntamente com outros de mesmo perfil, funda uma associação cultural - iniciativa de sucesso até que aparece um viajante alemão fazendo palestras sobre a superioridade germânica e criando constrangimento entre jovens que assumem sua nacionalidade brasileira. No final vence o Brasil Deutschtum, numa postura de conciliação entre a herança cultural alemã, a vinculação política (cidadania) ao Brasil e a participação na vida brasileira, com rejeição da visão mais pangermanista de superioridade. Resumindo: teutobrasilidade. O conto de Deeke foi escrito no início da década de 1930, época em que o partido nazista começava a atuar mais intensamente em algumas cidades com expressiva população de origem alemã. Possivelmente, estava se referindo a um palestrante vinculado ao nazismo, e seus personagens "locais" (inclusive alemães-novos, integrados na comunidade) servem de veículo para um posicionamento de pertencimento ao Brasil e de afirmação de uma germanidade legítima construída em solo brasileiro. O autor se incluía naquela parcela da elite local que não aceitou o discurso tutelar do nazismo, que considerava imigrantes e descendentes apenas como "hóspedes" do país de acolhida, e que deviam ser regermanizados.

A germanidade brasileira enfatizada por Deeke, com o devido respaldo da cidadania, é uma apologia da comunidade étnica formada no Brasil. Louva-se a colônia, a Kolonistenleben, de forma mais apologética no caso da poesia, mas igualmente alguns valores culturais preservados pela elite mais culta e educada. Afinal, no conto de Deeke os jovens (colonos) podem aprender sobre cultura alemã e Deutschtum numa associação.

Finalmente, uma breve menção à produção literária de Therese e Gustav Stutzer (ele, pastor evangélico), que viveram no Brasil por duas décadas, a maior parte do tempo em Blumenau. Suas obras tiveram 
repercussão na Alemanha, onde foram editadas em Braunschweig pela editora Wollermann: o livro de Gustav, Meine Therese (Minha Teresa), teve 29 edições, e a coletânea de contos sobre a imigração e a vida em Blumenau, de Therese, com o chamativo título Am Rande des brasilianischen Urwaldes (Na orla da floresta brasileira), chegou à décima edição em 1924 (cf. Huber, 1979, f. 100). Possivelmente chamaram a atenção do público alemão porque são narrativas que têm um componente exótico, não só relativo à natureza brasileira e sua "exuberância", mas também à própria vida peculiar dos imigrantes na dificultosa situação pioneira. Esses aspectos são mais visíveis no trabalho (quase autobiográfico) que Gustav Stutzer escreveu sobre sua mulher, descrevendo a passagem da família pelo Brasil e seu relacionamento com a população teuto-brasileira de Blumenau. A obra ficcional de Therese Stutzer fala da imigração, de imigrantes, da colônia, a partir de histórias quase sempre trágicas (triângulos amorosos, maridos traídos quando deixam as esposas para viajar à Alemanha, assassinato de um brasileiro ao fazer a corte a uma jovem da colônia já comprometida, etc.).

Veja-se, por exemplo, o conto Marie Louise: é uma história de casamentos arranjados de acordo com a tradição, adultério e outros temas universais. Mas os diálogos apontam para a beleza da paisagem, o conflito envolvendo imigrantes recém-chegados e os já estabelecidos; Blumenau é apresentada como um lugar germanizado, espécie de continuidade da "terra natal”, a colônia é o melhor lugar para se viver no Brasil, e a Alemanha torna-se uma pátria objeto de estranhamento quando um dos personagens viaja para uma visita aos parentes e "descobre” que sua Heimat está no Brasil.

Dito de outra forma, contos e novelas, além do conteúdo propriamente ficcional que trata de dramas humanos envolvendo imigrantes, são veículos para divulgar o que Deeke chamou de Brasil Deutschtum - uma expressão de etnicidade - sem os recursos metafóricos empregados na poesia.

Muitos outros temas relacionados à imigração e colonização estão contidos nos contos e romances, relativos à vida doméstica, família, casamento, religião, lazer, sociabilidade, convivência nas associações, trabalho familiar, opiniões sobre os brasileiros e seus costumes - enfim, apresentam versões sobre a vida cotidiana e, eventualmente, sobre as relações com a pátria de origem. Nos escritos femininos os personagens 
centrais quase sempre são mulheres, destacando-se seu papel no âmbito da colônia, inclusive na manutenção da cultura alemã. Renaux (1995), por exemplo, utilizou textos de Gertrud Gross Hering e Therese Stutzer como fontes para mostrar a participação feminina na história do Vale do Itajaí. Não creio que seja possível usá-los como se fossem documentos históricos, ou valorizá-los sociologicamente, como sugere Huber (1979). Mas, por outro lado, resultam da vivência dos seus autores no complexo colonial, documentos únicos, representações sobre um estilo de vida e visão de mundo articulados à noção de germanidade. Seus personagens não são colonos comuns, estão antes num lugar urbano - Stadtplatz.

Além disso, há nessa literatura um assunto onipresente, embora nem sempre explicitado: o preconceito contra os brasileiros, principalmente aqueles que nas regiões coloniais de Santa Catarina são chamados caboclos. É interessante observar nos escritos a idealização de uma comunidade étnica homogênea. No entanto, o Vale do Itajaí recebeu muitos imigrantes italianos e poloneses a partir do último quartel do século XIX; na elite local figuravam alguns luso-brasileiros (uma designação de conotação racial que distingue notáveis de caboclos) ocupantes de cargos públicos ou profissionais liberais; e o desenvolvimento industrial começou a atrair brasileiros desde a década de 1920. Mesmo assim, é mais fácil encontrar um personagem filho de imigrantes em contato com brasileiros em Santos ou Curitiba (portanto, em situação de viagem) do que em Blumenau.

Na primeira metade do século XX havia várias categorias para brasileiros, principalmente de baixa renda, que buscavam trabalho ou terra nas áreas coloniais: Schlammburger (cf. Albersheim, 1962), morador da lama, numa associação com a casa de taipa, usada na colônia Hansa; Eidecksen (cf. Seyferth, 1982), lagartos, uma metáfora que estigmatiza a preguiça; ou, simplesmente, caboclo, termo que não detonava, necessariamente, miscigenação. Na região mais alta do Vale do Itajaí era usada a categoria fanático, um termo para designar a população cabocla envolvida na guerra do Contestado. Na definição preconceituosa estavam em oposição (como até hoje) o ethos do trabalho germânico e a indolência e preguiça imaginadas como defeitos inatos dos caboclos. Na literatura esse preconceito pode estar apenas insinuado, ao eleger o casamento endogâmico como situação ideal, por exemplo, nos contos Mutter Wantken (Mãe Wantken), de Gertrud Gross Hering, e Nur ein Kolonistenmädchen 
(Apenas uma moça da colônia), de Therese Stetzer. Ou pode ser externalizado na sua forma mais comum, relacionada à "preguiça cabocla", como nessa passagem de um texto de Gustav Stutzer transcrito por Renaux (1995, p. 109):

O sentido da vida do trabalhador e colono brasileiro é não fazer nada. Os homens ficam sentados diante da choupana até serem obrigados a fazer alguma coisa para não morrer de fome; as mulheres igualmente, desprezam o trabalho e ficam o dia todo debruçadas nas janelas.

A estereotipia associada ao trabalho, mesmo na literatura, advém da própria idéia de Deustschtum em sua dimensão, por assim dizer, prática, pois é usada para exaltar a contribuição econômica dos imigrantes para a nova pátria (ou Deutsche Mitarbeit) como parte do sucesso civilizatório do desbravamento e colonização. Nessa dimensão do "trabalho alemão" não há espaço para o brasileiro; ele é situado na periferia da colônia. Embora na ficção apareçam personagens (economicamente) fracassados, quase sempre imigrantes recém-chegados, seu insucesso é atribuído, invariavelmente, a problemas emocionais decorrentes da situação imigratória (inclusive saudades de "velha pátria") ou a conflitos com o ambiente cultural teutobrasileiro.

V

Uma Alemanha no seio do Brasil

A frase em epígrafe encerra uma carta de Therese Stutzer a familiares, da qual emergem detalhes de sua vida em Blumenau (a "Alemanha" no Brasil). ${ }^{28}$ Representa a síntese do Brasil Deutschtum, ou Deutschbrasilianertum, ou outras palavras compostas, surgidas nas publicações teuto-brasileiras anteriores à campanha de nacionalização do Estado Novo, que articulam pertencimentos nacionais aparentemente contraditórios. Na poesia e, de modo geral, na literatura em língua alemã

${ }^{28}$ As cartas de Therese Stutzer são minuciosas ao narrar o cotidiano na colônia, e serviram de base para o livro Meine Therese, de Gustav Stutzer. O casal viveu em Blumenau nas décadas de 1880/90, mantendo boas relações com a elite local. Algumas dessas cartas, inclusive a que contém a citação em epígrafe, foram transcritas por Renaux (1995).

Horizontes Antropológicos, Porto Alegre, ano 10, n. 22, p. 149-197, jul./dez. 2004 
produzida em contexto teuto-brasileiro, o Brasil é, quase sempre, natureza e a colônia, cultura alemã. Não chega a ser uma divisão dicotômica, pois o lugar culturalmente diferenciado faz parte de um território e uma natureza convertidos em Heimat. Assim, a noção de ambivalência usada por Willems (1940, 1980) no sentido estritamente etimológico, e apropriada por Huber (1979, f. 53-54) para apresentar o "homem dualista" teuto-brasileiro, tendo em vista a literatura, não parece suficiente, apesar de ambos perceberem que esse produto de dois sistemas culturais distintos (e opostos) produz um terceiro - "abrasileirado", “aculturado", "híbrido". Nessa perspectiva, o teuto-brasileiro é um "homem marginal” (Willems, 1940), um "ser dividido", "dual" (Huber, 1979) entre dois mundos, explicação que supõe um certo antagonismo que, na verdade, não se revela no discurso étnico subjacente à produção literária, nem tampouco nas construções identitárias que transitam no cotidiano (cf. Seyferth, 1982).

As metáforas e representações sobre a teuto-brasilidade contidas nos textos literários apontam para etnicidade, um conceito atinente à cultura ou, como observou Jenkins (1997, p. 165), uma das suas dimensões diz respeito à diferenciação cultural, articulada à identidade enquanto dialética entre similaridade e diferença, sem esquecer que está enraizada na interação social. Barth (1969) chamou a atenção para a ação recíproca que marca as relações interétnicas, afirmando que a identidade étnica não é algo imutável, mas situacionalmente variável e em permanente negociação, daí sua ênfase na fronteira intergrupal e na interação dos atores sociais através dela.

A fronteira está presente nos enunciados literários, só que construída de dentro, numa versão (ou versões) sobre a etnicidade concernente à parcela da população colonial detentora de capital político, econômico e cultural. O compartilhamento de uma cultura é essencial nessa concepção de etnicidade, portanto não é dimensão irrelevante na produção da diferença que estrutura a fronteira simbólica da etnia (ou Volk). Nesse caso, o conteúdo cultural - as “características diacríticas” que delimitam a identidade e as "orientações valorativas básicas” do grupo, nos termos de Barth (1969, p. 14) - é um aspecto importante a ser considerado, pois permite distinguir a etnicidade de outras categorias de pertencimento comunitário.

Nesse caso, poesia, contos, romances, crônicas, publicados em periódicos locais ou regionais, são produtos de pessoas pertencentes a uma elite educada, e refletem suas estratégias simbólicas para compor o grupo 
étnico. Também revelam a tensão em jogo na configuração de uma identidade específica, unívoca, frente a um Estado-Nação assimilacionista que é, igualmente, a nova Vaterland. Essa literatura prosperou na República, num período de exacerbação do nacionalismo brasileiro marcado por várias crises relacionadas à imigração alemã - inclusive a declaração do estado de guerra com a Alemanha em 1917, após duas décadas de discussão sobre o "perigo alemão". Falava-se em secessão, na necessidade de forçar o "abrasileiramento", com ênfase na nacionalização do ensino e no cerceamento do uso da língua alemã, prenunciando a repressão mais ampla durante o Estado Novo. A produção literária intensificou-se na década de 1920, período marcado pelo aumento da imigração alemã e, igualmente, por aquilo que Willems (1980, p. 107-109) chamou de "quebra do insulamento cultural”, condicionado pela diferenciação interna dos núcleos coloniais, pela industrialização acompanhada da urbanização, e pela ascensão social que requeria o domínio da língua nacional e a própria assimilação. Por outro lado, a emancipação das colônias ocorrida no final do Império, com a criação dos municípios de Blumenau, Brusque e Joinville, abriu espaço para reivindicações políticas, resultando, entre outras coisas, na formação de grupos políticos teuto-brasileiros num período em que o Vale do Itajaí tornouse o mais importante colégio eleitoral do Estado de Santa Catarina. Ao lado disso, o crescimento econômico atraiu brasileiros para as regiões de colonização, em busca de emprego industrial, aumentando a diversidade étnica até então limitada à imigração de italianos e poloneses para assentamento em linhas coloniais. Resumindo, a literatura teuto-brasileira floresceu em contexto interétnico, num período de integração políticoeconômica de uma parcela da sociedade colonial que, dentro dos cânones do nacionalismo romântico alemão, reivindicava uma identidade cultural específica - Kultur, também em sentido civilizatório.

O Gedenkbuch editado por Entres (1929) é uma síntese da germanidade à brasileira (Brasil Deutschtum), expressada na forma simbólica principalmente na poesia e, em tom laudatório, na história da colonização, nas biografias dos "notáveis", inclusive literatos, e nos artigos finais sobre Deutschtum e as associações culturais e recreativas. Há destaque específico para a família Konder, então detentora do poder político no estado. Mas a maior parte do volume tem autoria de Gottfried Entres, e de José Deeke, ex-diretor de colônia, que escreveu os textos, sobre a 
história da colonização alemã. ${ }^{29}$ O conteúdo aponta para o que Kuder (1936/ 37) chamou de Bodenständigkeitsgefühl der deuschen Volksgruppe in Brasilien - para o autor, um indicador do sentimento nacionalista (inconsciente) em relação à terra brasileira. Isso é observado, como mostrei, em romances onde um personagem viaja para a Alemanha e lá se sente um estranho, desejoso de voltar para o seu lar no Brasil - a colônia! Só que a colônia é uma imaginada comunidade teuta, e esta é celebrada no Gedenkbuch como produto da germanidade. Ali está destacada, como na poesia e nos romances, a diferença cultural articulada à ancestralidade alemã: a Urwald transformada em prósperas colônias onde floresce a vida germânica.

Essa "vida germânica” tem uma dimensão específica na pequena cidade (Stadplatz), representada pelas associações, pelas reuniões em casas particulares, até pelo teatro que surge em Blumenau antes da emancipação política, configurando uma sociabilidade articulada à noção de Kultur inspirada em valores burgueses do século XIX e nos discursos nacionalistas do Romantismo alemão. No seu trabalho sobre o papel da mulher no Vale do Itajaí, Renaux (1995) mostra certos padrões burgueses próprios das famílias que enriqueceram, visíveis na arquitetura, jardins, vestuário, ambiente doméstico, destacando, no plano cultural, a criação do teatro Frohsin e sua principal mentora, Roese Gaertner. A questão que surge é: por que em Blumenau houve esse empenho por uma vida cultural propriamente germânica no seu enunciado? Houve o crescimento econômico, famílias enriqueceram na atividade comercial que embasou a industrialização, havia uma ligação com a Alemanha, país de onde importavam jornais, revistas e livros (entre outras coisas), tinham um projeto político que se concretizou em algumas trajetórias de projeção nacional. Mas, além disso, havia a figura carismática do fundador da colônia. Hermann Blumenau era formado em Química pela Universidade de Erlangen, cidade natal de von Martius, onde conheceu figuras importantes nos meios acadêmicos, como o geógrafo J. E.

${ }^{29}$ Há outros colaboradores que tratam de temas mais específicos, como o padre S. Schätte e os pastores Richter e H. Muller, que escreveram sobre as comunidades católica e evangélicaluterana, e Marcos Konder, que escreveu sobre a escola alemã. Além dos escritores, o volume destaca as biografias de Lauro Muller, Felipe Schmidt (que governaram o Estado), Raulino Horn (um político que chegou ao Congresso Nacional), Hermann Blumenau e Ottokar Doerffel (administradores coloniais), Carl Hoepcke e Ernesto Vahl (grandes comerciantes); têm maior destaque os artigos referentes a Marcos Konder e seus filhos, particularmente o então governador Adolpho Konder. 
Wappäus e Alexandre von Humboldt, que viajaram pelo Brasil. Além disso, manteve relação de amizade com o cônsul-geral do Brasil na Prússia, Johan J. Sturtz. Essas pessoas o incentivaram a levar adiante seu projeto de colonização (decidido após uma viagem ao Brasil como membro da Sociedade de Proteção aos Imigrantes Alemães no Sul do Brasil). Isto tornou a colônia bastante conhecida na Alemanha, e o próprio Blumenau convenceu algumas pessoas com escolaridade acima da média do imigrante comum, como o naturalista Fritz Muller, Reinold Gaertner (seu sobrinho), o engenheiro Emil Odebrecht, entre outros, a enfrentar a vida colonial. Imigrantes como a família Hering, por exemplo, apesar das dificuldades econômicas enfrentadas na Alemanha, não eram comuns, pois possuíam recursos para se estabelecer no comércio - o que não era o caso dos colonos em geral, localizados nas linhas coloniais. Criou-se, assim, um ambiente propício às atividades culturais e associativas, incentivadas pelo próprio fundador da colônia, da qual foi diretor durante 23 anos, até a criação do município em 1883. Nesse ambiente onde, nos termos de Therese Stutzer, recriava-se a Alemanha, também transitavam os escritores nenhum deles colono em sentido estrito. Aliás, a obra de Gustav e Therese Stutzer ajudou a divulgar esse perfil germanizado no seio da floresta brasileira devidamente domesticada pelo "trabalho alemão" - lembrando que as primeiras edições dos seus livros foram publicadas a partir de 1886.

Mas o colono comum, assim como os habitantes da cidade, além de personagem de muitas histórias, fazia parte do público-alvo dessa produção literária de circulação restrita. Concretamente, ela forneceu os elementos próprios da identidade étnica num idioma escrito acessível a uma população de baixa escolaridade de certa forma ciosa das suas tradições, embora não freqüentasse o ambiente culto do teatro e dos salões da elite urbana. Não interessa o debate sobre a baixa qualidade literária corroborado por Kuder e Willems ao manifestar sua reprovação estética de escritos destinados ao "consumo de leitores cuja maioria, apenas alfabetizada, não é capaz de elevar-se acima do nível mais rudimentar” (Willems, 1980, p. 393). O que importa registrar é aquilo que Ernesto Niemeyer reivindicou no artigo Teutonen Literatur, já citado: na nova pátria os teutões têm vida própria, e por isso têm direito a uma literatura própria - que não é uma literatura alemã, mas teuto-brasileira, escrita em língua alemã. A influência do meio brasileiro não é subestimada por Niemeyer, nem tampouco a germanidade. 
Nos limites da noção de Kultur - um termo também denotativo de civilização - a literatura contém os elementos diferenciadores da comunidade étnica, seja na forma metafórica da poesia, oscilando entre as belezas e mistérios da Urwald e o delineamento da vida civilizada alemã, seja nos contos, romances e crônicas, onde aparecem mais concretamente as manifestações de etnicidade, através de personagens não integrados à sociedade colonial, e da descrição dos valores próprios associados à imigração. Sobretudo, a literatura também era um meio de divulgar a língua alemã, a característica diacrítica mais importante da identidade cultural, conforme se observa nas inúmeras matérias sobre a "língua materna” que saíram nos Kalender e jornais a partir da década de 1920, ante a ameaça de nacionalização. De certa forma, a literatura procurou balancear a tensão entre etnicidade e nacionalismo, apontando para as especificidades locais próprias da germanidade e afirmando o inequívoco pertencimento à pátria brasileira.

\section{Referências}

ALBERSHEIM, Úrsula. Uma comunidade teuto-brasileira (Jarim). Rio de Janeiro, CBPE-INEP/MEC, 1962.

BARTH, Fredrik. Introduction. In: BARTH, Fredrik. (Ed.). Ethnic Groups and Boundaries. Bergen/Oslo: Universitetsforlaget; London: George Allen and Unwin, 1969. p. 9-38.

CARNEIRO, J. F. Imigração e colonização no Brasil. Rio de Janeiro: Faculdade Nacional de Filosofia, 1950. Publicação avulsa.

D’AMARAL, Max Tavares. Contribuição à história da colonização alemã no Vale do Itajaí. São Paulo: Instituto Hans Staden, 1950.

DEUTSCHE Worte. São Leopoldo: Rotermund, [s.d.].

ENTRES, Gottfried (Ed.). Gedenkbuch zur Jahrhundertfeier deutscher Einwanderung in Santa Catharina. Florianópolis: Livraria Central, 1929. FAUSEL, Erich. Die Deutschbrasilianische Sprachmischung. Berlin: E. Schmidt, 1959.

FREYRE, Gilberto. Uma cultura ameaçada: a luso-brasileira. Recife, 1940. Edição do autor.

GERTZ, René. O perigo alemão. Porto Alegre: Editora da Universidade/ 
UFRGS, 1991.

HOBSBAWM, Eric J. Nações e nacionalismo desde 1780. Rio de Janeiro: Paz e Terra, 1990.

HUBER, Walburga. Saudade e esperança: dualismo do imigrante alemão refletido em sua literatura. Dissertação (Mestrado em Letras Vernáculas)Faculdade de Letras, Universidade Federal do Rio de Janeiro, Rio de Janeiro, 1979.

HUBER, Walburga. Saudade e esperança. Blumenau: Ed. FURB, 1993. HUBER, Walburga. Natureza na literatura teuto-brasileira: paraíso natural x paraíso construído. Blumenau em Cadernos, v. 43, n. 11/12, p. 34-43, 2002.

HUBER, Walburga. "O sentimento patriótico na literatura teuto-brasileira”. In: Blumenau em Cadernos, v. 44, n. 1/2, p. 52-60, 2003.

HUNDERT Jahre Deutschtum in Rio Grande do Sul. São Leopoldo: Verband Deutscher Vereine, 1924.

JENKINS, Richard. Rethinking ethnicity: arguments and explorations. London: Sage, 1997.

KORMANN, Edith. Blumenau: arte, cultura e as histórias de sua gente (1850-1985). Florianópolis: Paralelo 27, 1994.

KUDER, Manfred. Die deutschbrasilianische Literatur and das Bodenständigkeitsgefühl der deutschen Volksgruppe in Brasilien. Ibero Amerikanisches Archiv, v. 10, n. 4, p. 394-494, 1936/37.

LIEBE und Heimat. São Paulo: Weizflog Irmãos, 1916.

LINTON, Ralph. Acculturation in Seven American Indian Tribes. New York: Appleton, 1940.

MEMORIAL do Pastor Wilhelm G. Lange. Blumenau: Nova Letra, 2003. OBERACKER JUNIOR, Carlos H. A contribuição teuta à formação da nação brasileira. Rio de Janeiro: Presença, 1968.

PARK, Robert. Human migration and the marginal man. American Journal of Sociology, 33, p. 881-893, 1928.

PUFF, Lia C. (Org.). Uma enteada da natureza: Gertrud Gross Hering. Florianópolis: Ed. UFSC; Blumenau: Cultura em Movimento, 2000.

REDFIELD, Robert; LINTON, Ralph; HERSKOVITS, Melville J. 
Outline for the study of Acculturation. American Anthropologist, n.s., 38, p. 149-152, 1935.

RENAUX, Maria Luiza. O papel da mulher no Vale do Itajaí - 18501950. Blumenau: Editora da FURB, 1995.

ROCHE, Jean. A colonização alemã e o Rio Grande do Sul. Porto Alegre: Globo, 1969.

SCHAPPELLE, B. F. The german element in Brazil: colonies and dialect. Philadelphia: Americana Germanica Press, 1917.

SEYFERTH, Giralda. Nacionalismo e identidade étnica. Florianópolis: Fundação Catarinense de Cultura, 1982.

SEYFERTH, Giralda. Imigração e cultura no Brasil. Brasília: Editora UnB, 1990.

SEYFERTH, Giralda. O incidente do Panther (Itajaí, S.C., 1905): estudo sobre ideologias étnicas. Antropologia Social: Comunicações do PPGAS, 4, p. 15-80, 1994.

SEYFERTH, Giralda. Os imigrantes e a Campanha de Nacionalização do Estado Novo. In: PANDOLFI, Dulce (Org.). Repensando o Estado Novo. Rio de Janeiro: Ed. Fundação Getúlio Vargas, 1999a.

SEYFERTH, Giralda. As associações recreativas nas regiões de colonização alemã no sul do Brasil: Kultur e etnicidade. Travessia, ano 12, n. 34, p. 24-28, 1999b.

SEYFERTH, Giralda. As identidades dos imigrantes e o melting-pot nacional. Horizontes Antropológicos, Porto Alegre, ano 6, n. 14, p. 143176, 2000.

SEYFERTH, Giralda. Colonização, imigração e a questão racial no Brasil. Revista USP, 53, p. 117-149, 2002a..

SEYFERTH, Giralda. Estudo sobre reelaboração e segmentação da identidade étnica. Cadernos CERU, Série 2, n. 13, p. 9-36, 2002b. SILVA, José Ferreira da. História de Blumenau. Florianópolis: Edeme, [s.d.].

STONEQUIST, E. V. O homem marginal. São Paulo: Martins, 1948. THOMAS, William I.; ZNANIECKI, F. The Polish Peasant in Europe and America. New York: Octagon Books, 1974. 
UMANN, Josef. Memórias de um imigrante boêmio. Tradução e notas de Hilda Hübner Flores. Porto Alegre: EST, 1981

WEBER, Max. Economia e sociedade. Brasília: Ed. UnB, 1991.

WILLEMS, Emílio. Assimilação de populações marginais no Brasil. São Paulo: Companhia Editora Nacional, 1940.

WILLEMS, Emílio. A aculturação dos alemães no Brasil. 2. ed. São Paulo: Companhia Editora Nacional, 1980.

Recebido em 01/08/2004

Aprovado em 02/08/2004 